\title{
Distribution, origin and cycling of carbon in the Tana River (Kenya): a dry season basin-scale survey from headwaters to the delta
}

\author{
S. Bouillon ${ }^{1,2,3}$, G. Abril ${ }^{4}$, A. V. Borges ${ }^{5}$, F. Dehairs ${ }^{2}$, G. Govers ${ }^{1}$, H. J. Hughes ${ }^{6}$, R. Merckx ${ }^{1}$, F. J. R. Meysman ${ }^{2,3}$, \\ J. Nyunja ${ }^{7}$, C. Osburn ${ }^{8}$, and J. J. Middelburg ${ }^{3,9}$ \\ ${ }^{1}$ Katholieke Universiteit Leuven, Dept. of Earth \& Environmental Sciences, Kasteelpark Arenberg 20, 3001 Leuven, Belgium \\ ${ }^{2}$ Dept. of Analytical and Environmental Chemistry, Vrije Universiteit Brussel, Belgium \\ ${ }^{3}$ Netherlands Institute of Ecology, Centre for Estuarine and Marine Ecology, Yerseke, The Netherlands \\ ${ }^{4}$ Environnements et Paléoenvironnements Océaniques, Université Bordeaux 1, France \\ ${ }^{5}$ Unité d'Océanographie Chimique, Université de Liège, Belgium \\ ${ }^{6}$ Royal Museum for Central Africa, Dept. of Geology, Tervuren, Belgium \\ ${ }^{7}$ Kenya Wildlife Service, P.O. Box 40241-00100, Nairobi, Kenya \\ ${ }^{8}$ Department of Marine, Earth \& Atmospheric Sciences, NC State University, Raleigh, USA \\ ${ }^{9}$ Faculty of Geosciences, Utrecht University, PO Box 80021, 3508 TA Utrecht, The Netherlands
}

Received: 9 June 2009 - Published in Biogeosciences Discuss.: 22 June 2009

Revised: 26 October 2009 - Accepted: 27 October 2009 - Published: 5 November 2009

\begin{abstract}
The Tana River basin (TRB) is the largest in Kenya $\left(\sim 120000 \mathrm{~km}^{2}\right)$. We conducted a survey during the dry season throughout the TRB, analyzing a broad suite of biogeochemical parameters. Biogeochemical signatures in headwater streams were highly variable. Along the middle and lower river course, total suspended matter (TSM) concentrations increased more than 30 -fold despite the absence of tributary inputs, indicating important resuspension events of internally stored sediment. These resuspended sediment inputs were characterized by a lower and ${ }^{14} \mathrm{C}$-depleted OC content, suggesting selective degradation of more recent material during sediment retention. Masinga Dam (a large reservoir on the upper river) induced a strong nutrient retention ( $\sim 50 \%$ for inorganic $\mathrm{N}, \sim 72 \%$ for inorganic phosphate, and $\sim 40 \%$ for dissolved silicate). Moreover, while DOC pools and $\delta^{13} \mathrm{C}$ signatures were similar above, in and below the reservoir, the POC pool in Masinga surface waters was dominated by ${ }^{13} \mathrm{C}$-depleted phytoplankton, which contributed to the riverine POC pool immediately below the dam, but rapidly disappeared further downstream, suggesting rapid remineralization of this labile $\mathrm{C}$ pool in the river system. Despite the generally high turbidity, the combination of relatively high oxygen saturation levels, low $\delta^{18} \mathrm{O}$ signatures of dissolved $\mathrm{O}_{2}\left(\right.$ all $<+24.2 \%$ ), and the relatively low $p \mathrm{CO}_{2}$
\end{abstract}

Correspondence to: S. Bouillon (steven.bouillon@ees.kuleuven.be) values suggest that in-stream primary production was significant, even though pigment data suggest that phytoplankton makes only a minor contribution to the total POC pool in the Tana River.

\section{Introduction}

River systems represent the primary pathway for carbon transport from the terrestrial to the marine environment, and are thus critical in determining the quantity and composition of carbon reaching the coastal zone. A recent data compilation suggests a substantial transfer of $\sim 2 \mathrm{PgC}^{-1}$ from the terrestrial biome into freshwater systems, yet less than half of this is estimated to reach the ocean (Cole et al., 2007). Accordingly, a substantial amount of terrestrial $\mathrm{C}$ is processed or stored within freshwater systems, which are typically strong net sources of $\mathrm{CO}_{2}$ to the atmosphere (Cole et al., 1994; Cole and Caraco, 2001; Duarte and Prairie, 2005). Freshwater systems thus function as biogeochemical "hotspots" on the land-ocean interface (McClain et al., 2003). Due to the overwhelming evidence for a high degree of biogeochemical processing of organic matter in freshwater systems (e.g., Wollheim et al., 2006; Cole et al., 2007; Battin et al., 2008), the original view of rivers as mere inactive conduits for organic matter and nutrients has thus significantly evolved. There is evidence that millennia-old organic

Published by Copernicus Publications on behalf of the European Geosciences Union. 
matter from soils can undergo surprisingly high degree of remineralization on a time scale of weeks after entering the aquatic system (Raymond and Bauer, 2001; see also Cole and Caraco, 2001), even though a smaller pool of more recent material may dominate overall remineralization (Mayorga et al., 2005; Holmes et al., 2008). Considering the various organic matter inputs in rivers, and large differences in the potential for carbon processing and exchange (e.g. from temperate to tropical environments, presence of flood plains, etc.), carbon cycling in rivers is in reality much more complex than the "pipeline versus reactor" view (see Cole et al., 2007) on river carbon cycling suggests: various fractions of dissolved and particulate organic carbon (DOC and POC) are likely to have different reactivities and thus, may be modified or remineralized very differently (Mayorga et al., 2005; del Giorgio and Pace, 2008). Key factors in determining the overall degree of organic matter processing in river networks are the presence and extent of hydrological retention and storage events or zones such as floodplains, deposition/resuspension of suspended sediment (Meybeck and Vörösmarty, 2005; Battin et al., 2008). Although the important role of freshwater systems in carbon cycling is now well recognized, current data leave us far from reaching well-constrained global estimates of respiration in rivers and streams (Battin et al., 2008). A better understanding of terrestrial-aquatic linkages is not only important to improve global estimates of $\mathrm{C}$ processing in rivers, but also fundamental to our understanding of the impact of ongoing and future land use changes. Many tropical and subtropical catchment areas suffer from intensive deforestation in upland areas, resulting in an increased delivery of eroded sediment to the river system. Increasing demand for energy (hydropower stations) and water resources (e.g. for irrigation schemes) has led to a proliferation in the number of dams and reservoirs, which have a large impact on the nutrient status and sediment delivery downstream (e.g., Ittekkot et al., 2000, Vörörsmarty et al., 2003; Snoussi et al., 2007). As terrestrial organic matter is often the dominant carbon input in river systems (Bird et al., 1994, Martinelli et al., 1999; Coynel et al., 2005), landuse changes can in some cases be rapidly reflected in riverine carbon and nutrient pools (e.g., Bernardes et al., 2004; Raymond et al., 2008). There is a growing body of literature documenting the significant changes in organic matter characteristics in estuaries and coastal areas, indicating that the output (i.e., organic matter exported to the coastal ocean) can differ substantially in quantity and quality from the inputs (i.e., that delivered to the estuarine zone through rivers) (e.g., Abril et al., 2002; McCallister et al., 2004; Bouillon et al., 2007). A similar process can be acting in the river system itself: biogeochemical processing of carbon during its transit in river systems implies that organic matter reaching the estuarine zone is likely to be different from the inputs received from land, both in terms of quantity and quality. Improving our understanding of the role of rivers in global C budgets will thus require a better understanding of the link between soil or catchment characteristics on the terrestrial side, subsequent particle transport and organic matter processing in rivers, and the ultimate $\mathrm{C}$ export and burial in the ocean (Masielo, 2007; Drenzek et al., 2009).

Data compilations on carbon fluxes in freshwater systems invariably indicate that the tropical regions are severely underrepresented, e.g. with respect to data on riverine carbon transport (Ludwig et al., 1996, see also Williams et al., 2007), carbon metabolism in lakes (Sobek et al., 2007) and rivers (Battin et al., 2008), and estuarine $\mathrm{CO}_{2}$ fluxes (Borges et al., 2005). In view of the importance of the tropics in overall riverine carbon transport and global carbon cycling in general (Ludwig et al., 1996), riverine carbon transport and processing in tropical systems and their relationship to (rapidly changing) land-use patterns is an important area for future studies.

Large-scale studies on carbon processing along the flowpath of low-latitude river basins have to date been concentrated on a very limited number of systems, e.g., the Orinoco basin, the Ganges-Brahmaputra (Aucour et al., 2006; Galy et al., 2008), rivers in Papua New Guinea (e.g., Alin et al., 2008) and in particular an extensive body of work on the Amazon river basin (e.g., Hedges et al., 1994; Richey et al., 2002; Mayorga et al., 2005; Townsend-Small et al., 2005, 2008; Johnson et al., 2006; Aufdenkampe et al., 2007). Biogeochemical characteristics in headwater streams of the Amazon are more variable than in the mainstream, reflecting regional differences in underlying geology and soil characteristics (Townsend-Small et al., 2005). The Andean tributaries are thought to be a principle source of suspended sediment and associated organic matter to the Amazon mainstream (see McClain and Naiman, 2008), but significant changes in organic matter characteristics have been observed. Townsend-Small et al. (2005) and Aufdenkampe et al. (2007) showed strong downstream patterns in the biogeochemical signatures of both fine and coarse POC, with e.g. highest $\% \mathrm{OC}, \% \mathrm{~N}$ and highest $\mathrm{POC} / \mathrm{PN}$ ratios in the highland tributaries. The latter has been suggested to be related to the lower degree of remineralization in high-altitude soils, with subsequently higher \%OC and $\mathrm{C} / \mathrm{N}$ ratios in soil organic matter.

In this study, we present data on various biogeochemical characteristics of a tropical river basin (Tana River, Kenya), along the flowpath from the high-altitude headwaters in perennial catchment areas (i.e., with discharge throughout the year), down to the lower river meandering through semiarid plains. An important characteristic of this river system is that a long section of the lower river $(>600 \mathrm{~km})$ does not receive any tributary inputs during the dry season, making it an ideal system to study within-river transformation processes. Using a large suite of parameters both on particulate and dissolved carbon pools and nutrients, we present a first basin-wide view on the inputs and processing of carbon in this tropical river basin. In particular, this paper discusses the general physico-chemical characteristics of different tributaries in the perennial catchment areas and along the main 


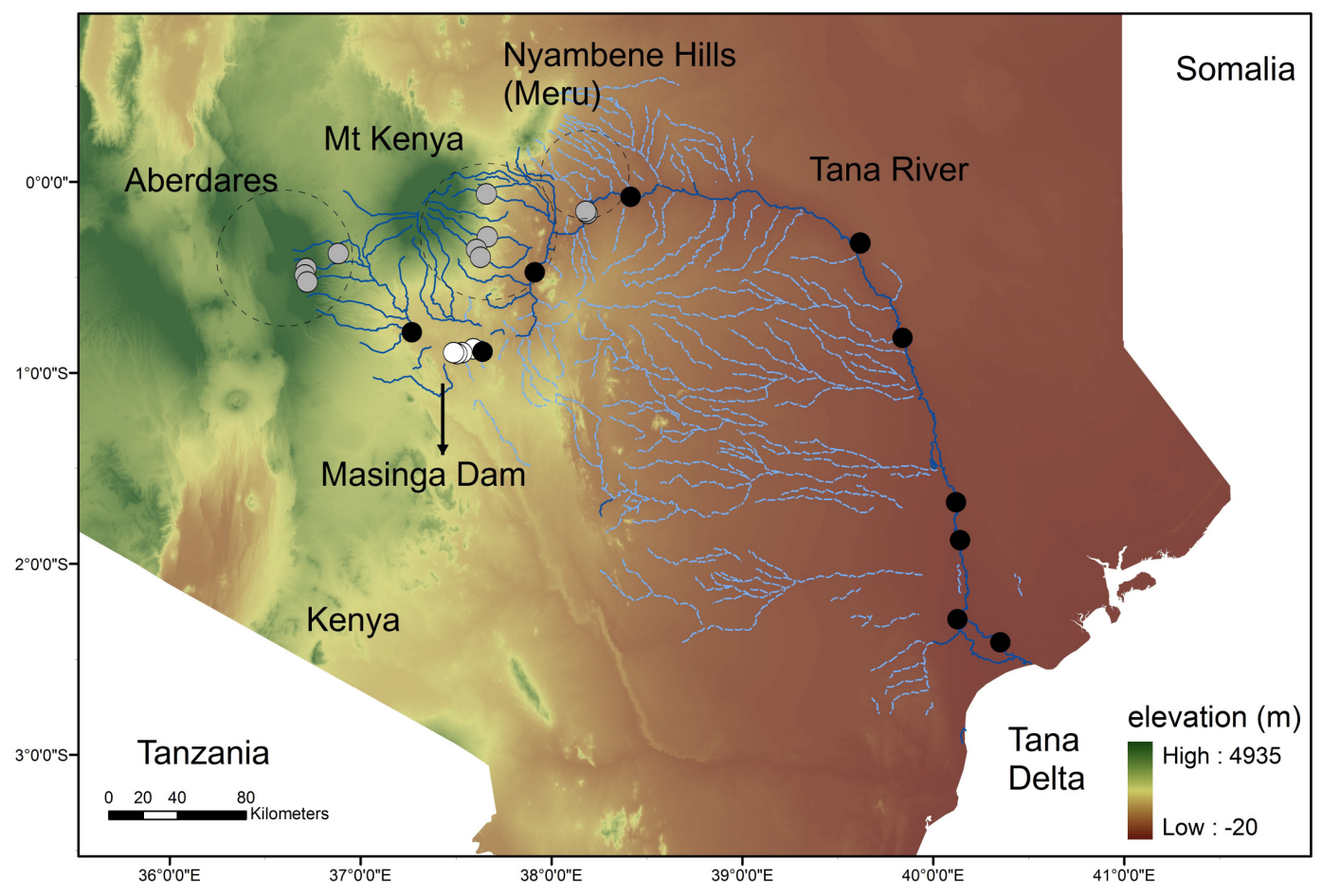

Fig. 1. Location of the Tana River basin and sampling locations. Black symbols: main Tana River; open symbols: Masinga reservoir; grey symbols: tributaries.

Tana River, the impact of Masinga dam on nutrient and different aquatic $\mathrm{C}$ pools, and the downstream trends in different $\mathrm{C}$ pools and their isotope composition. Studies of lowlatitude river systems have so far focussed on large, humid systems, and this study is the first to present biogeochemical data at the basin scale for a tropical river in a largely semiarid region.

\section{Materials and methods}

\subsection{Study area}

The Tana River originates in the vicinity of Mount Kenya and is the longest river system in Kenya $(\sim 1300 \mathrm{~km})$, with a catchment area of $\sim 120000 \mathrm{~km}^{2}$ (Kitheka et al., 2005). An average of $4 \mathrm{~km}^{3}$ of freshwater are discharged annually with peak flows occurring between April and June and a shorter high flow period during November/December. The sediment discharge carried to the Tana River mouth has been estimated at 3.1 and $6.810^{9} \mathrm{~kg} \mathrm{yr}^{-1}$ (Syvitski et al., 2005 and Kitheka et al., 2005, respectively). The three main perennial headwater regions are located in high-altitude regions, i.e. the Aberdare range (Nyandarua mountains), the southern and eastern slopes of Mount Kenya, and the Nyambene Hills (Fig. 1). Tributaries along the lower course between Meru National Park and and the delta (Tula Laga, Thua Laga, and Tiva Laga) only discharge during the wet season. Several irrigation schemes along this stretch, in addition to channel losses and evaporation result in a net reduction of water flow between Garissa and the coast during the dry season (Maingi and Marsh, 2002). A number of hydroelectric power dams have been constructed along the Tana River since the late 1960's, the largest of which is Masinga Dam which became operational in 1981 (Maingi and Marsh, 2002). The river enters the Indian Ocean roughly midway between Malindi and Lamu, near Kipini (Fig. 1), but part of the freshwater flow branches off into a complex network of tidal creeks, savannah-like flood plains, coastal lakes and mangrove swamps known as the Tana Delta (see Bouillon et al., 2007).

Sampling took place in February 2008, during dry season (low river flow) conditions. Samples or river water were taken in the three headwater regions, along several points on the main Tana River, and on the largest of the reservoirs (Masinga) - see details in Table 1 and Fig. 1. In the Aberdare range, 4 streams were sampled (Muringato river, Chania river, Maguru river, and Karuru river upstream of the Karuru falls) at altitudes of $\sim 2000 \mathrm{~m}$ (Muringato river) and $\sim 3000 \mathrm{~m}$ (the three other rivers). The vegetation in the Aberdares varies with altitude, with moist tropical montane forest in the lower range, gradually giving way to bamboo forests, Hagenia forest and tussock grasslands (moors) consisting of the $\mathrm{C} 4$ grass Andropogon amethystinus in the upper ranges. Along the southeastern slopes of Mount Kenya, 5 rivers were 
Table 1. Overview of sampling locations and selected water chemistry characteristics. Note that the full data are available as an electronic supplementary file.

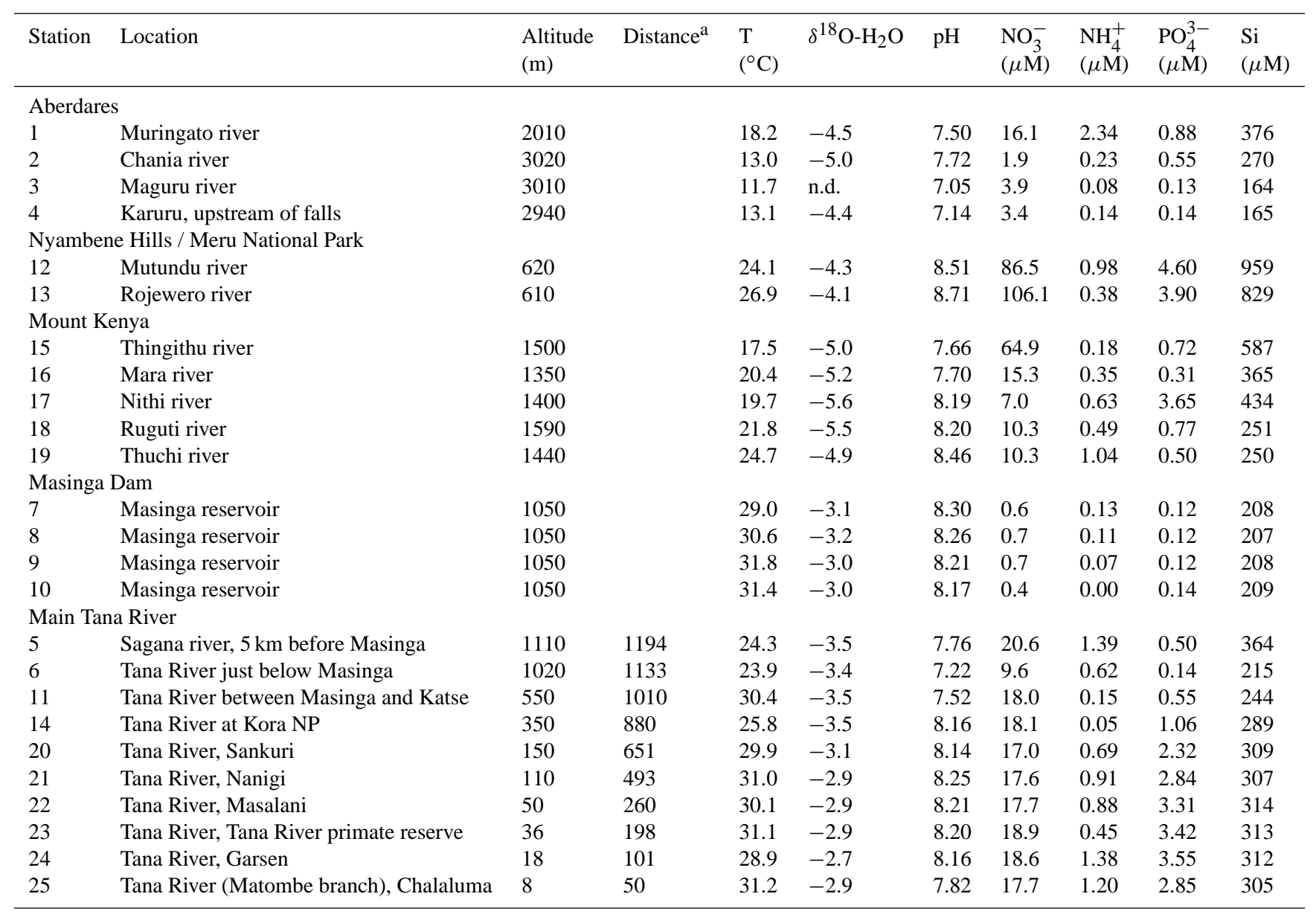

a Distance in km from the Tana River mouth at Kipini, calculated using the most northern branch of the Tana in its delta. Distances for the upper tributaries are not provided due to insufficient digital information on their exact course.

sampled roughly along the road between Meru and Embu (Thingithu, Mara, Nithi, Rugiti, and Thuchi river). These were sampled at an altitude between 1350 and $1600 \mathrm{~m}$, a zone which is largely farmland. Two perennial rivers (Mutundu river and Rojewero river) originating in the Nyambene Hills were sampled in Meru National Park (NP), close to their confluence with the Tana River at an altitude of $\sim 600 \mathrm{~m}$. Vegetation in Meru NP varies from open to closed-canopy savanna grasslands, with narrow bands of riverine forests along the perennial tributaries and along the Tana River. The main Tana River was sampled at 10 stations ranging in altitude from $1110 \mathrm{~m}$ to $\sim 10 \mathrm{~m}$ above sea level, encompassing an overall transect of $>1000 \mathrm{~km}$. The most upstream sampling stations along the main Tana River were located $\sim 5 \mathrm{~km}$ upstream and $\sim 500 \mathrm{~m}$ downstream of Masinga dam, with further sampling locations distributed along its further course until close to the river delta. The most downstream sampling station was located near Chalaluma on the Matomba branch of the Tana River, the Tana River braches out in this section but Matomba had the majority of discharge during the period of sampling (O. Hamerlynck and S. Duvail, personal communication, 2008). Below the Tana River sampling point on the border between Meru and Kora NP (i.e. over a length of $\sim 800 \mathrm{~km}$ ), no tributaries delivered water to the main river during the period sampled.

4 surface water samples were taken along a transect on the Masinga reservoir ( $1050 \mathrm{~m}$ altitude) from near the dam outflow to approximately the middle of the reservoir. Masinga is the largest of the reservoirs on Tana River $\left(\sim 120 \mathrm{~km}^{2}\right)$ and has an estimated mean water residence time of $\sim 3$ months, suggesting a potentially large impact on the sediment, carbon and nutrient transport further downstream. The sediment influx was found to be much larger than anticipated and a significant part of the original storage capacity has been lost, with an estimated annual sediment deposition rate of $\sim 10$ $1510^{6} \mathrm{~km}^{3} \mathrm{y}^{-1}$ (Dunne and Ongweny, 1976; Walling, 1984; 
Mutua et al., 2005). According to Schneider (2000), the sediment trapping efficiency of the dam ranges between 75 and $98 \%$, with most of the deposition occurring along the thalweg and little on the reservoir terraces (Saenyi, 2003). The suspended sediment load of the Tana River has considerably decreased since the dam construction (Kitheka et al., 2005), although there is evidence that this decrease in sediment transport already set in earlier (Dunne, 1977). Moreover, the flow regulation has led to major changes to the downstream river ecology, including a reduction in flood events, a reduction in the river meandering rate, and a reduction in riverine forests (see Maingi and Marsh, 2002).

\subsection{Sampling and analytical techniques}

Surface water for field measurements of dissolved $\mathrm{O}_{2}, \mathrm{pH}$, temperature, and salinity were taken with a $1.7 \mathrm{~L}$ Niskin bottle from $\sim 0.5 \mathrm{~m}$ below the surface. On the main Tana River, these were taken from bridges in the middle of the river wherever possible. Oxygen saturation level $\left(\% \mathrm{O}_{2}\right)$ was measured immediately after collection with a polarographic electrode (WTW Oxi-340) calibrated on saturated air, with an accuracy of $\pm 1 \%$. $\mathrm{pH}$ was measured using a combined electrode (Metrohm) calibrated on the NBS (US National Bureau of Standards) scale, as described by Frankignoulle and Borges (2001), with a reproducibility of $\pm 0.005 \mathrm{pH}$ units. Samples for determination of total alkalinity (TA) were obtained by pre-filtering $100 \mathrm{~mL}$ of water through precombusted Whatman GF/F filters, followed by filtration through $0.2 \mu \mathrm{m}$ Acrodisc syringe filters, and were stored in HDPE bottles until analysis by automated electro-titration on $50 \mathrm{~mL}$ samples with $0.1 \mathrm{~mol} \mathrm{~L}^{-1} \mathrm{HCl}$ as titrant (reproducibility estimated at $\pm 2 \mu \mathrm{mol} \mathrm{kg}^{-1}$ ). The partial pressure of $\mathrm{CO}_{2}$ $\left(p \mathrm{CO}_{2}\right)$ and total dissolved inorganic carbon (DIC) concentrations were computed from $\mathrm{pH}$ and TA measurements with the thermodynamic constants described in Frankignoulle and Borges (2001). The accuracy of computed DIC and $p \mathrm{CO}_{2}$ values are estimated at $\pm 5 \mu \mathrm{mol} \mathrm{kg}-1$ and $\pm 5 \mathrm{ppm}$, respectively.

Water samples for the analysis of $\delta^{13} \mathrm{C}_{\text {DIC }}$ and $\delta^{18} \mathrm{O}-\mathrm{O}_{2}$ were taken from the same Niskin bottle by gently overfilling $12 \mathrm{~mL}$ glass headspace vials, poisoning with $20 \mu \mathrm{L}$ of a saturated $\mathrm{HgCl}_{2}$ solution, and gas-tight capping with a butyl rubber septum and aluminum cap. For the analysis of $\delta^{13} \mathrm{C}_{D I C}$, a He headspace was created, and $\sim 300 \mu \mathrm{L}$ of $\mathrm{H}_{3} \mathrm{PO}_{4}$ was added to convert all inorganic carbon species to $\mathrm{CO}_{2}$. After overnight equilibration, part of the headspace was injected into the He stream of an elemental analyser - isotope ratio mass spectrometer (EA-IRMS, ThermoFinnigan Flash1112 and ThermoFinnigan Delta+XL) for $\delta^{13} \mathrm{C}$ measurements. The obtained $\delta^{13} \mathrm{C}$ data were corrected for the isotopic equilibration between gaseous and dissolved $\mathrm{CO}_{2}$ as described in Gillikin and Bouillon (2007). For $\delta^{18} \mathrm{O}_{-} \mathrm{O}_{2}$, a similar headspace was created, after which they were left to equilibrate for $2 \mathrm{~h} . \quad \delta^{18} \mathrm{O}-\mathrm{O}_{2}$ was then measured using the same EA-IRMS setup by monitoring $\mathrm{m} / \mathrm{z}, 32,33$, and 34 and using a molecular sieve ( $5 \ddot{\mathrm{A}}$ ) column to separate $\mathrm{N}_{2}$ from $\mathrm{O}_{2}$. Outside air was used as the internal standard to correct all $\delta^{18} \mathrm{O}$ data. The $0.5 \mathrm{~mL}$ of water removed to create the headspace for the $\delta^{18} \mathrm{O}_{D O}$ analyses was used to determine $\delta^{18} \mathrm{O}$ signatures of $\mathrm{H}_{2} \mathrm{O}$ according to Gillikin and Bouillon (2007).

Samples for $\mathrm{CH}_{4}$ were collected directly from the Niskin bottle in $40 \mathrm{~mL}$ headspace vials, poisoned with $\mathrm{HgCl}_{2}$, and closed with a rubber septum and aluminum cap. $\mathrm{CH}_{4}$ concentrations were determined by gas chromatography, after creating a headspace with $\mathrm{N}_{2}$, as described in Abril and Iversen (2002). Dissolved $\mathrm{CH}_{4}$ concentrations were calculated using the solubility coefficient of Yamamoto et al. (1976). Samples for ammonium, nitrate, phosphate, and silicate were obtained by pre-filtration on $47 \mathrm{~mm}$ GFF filters and subsequent filtration on $0.2 \mu \mathrm{m}$ Acrodisc syringe filters, preserved with $\mathrm{HgCl}_{2}\left(1 \mu \mathrm{L} \mathrm{mL}^{-1}\right.$ sample), and analysed with automated colorimetric techniques. A subset of samples for $\mathrm{SiO}_{2}$ were prepared by filtration on $0.45 \mu \mathrm{m}$ membrane filters to check for possible artifacts caused by the prefiltration procedure with glassfibre filters, but no deviations in concentrations were found.

Samples for TSM were taken with sampling bottles at $\sim 0.5 \mathrm{~m}$ below the water surface, or using a bucket when sampling from bridges along the main river. These were filtered immediately in the field on pre-weighed and precombusted (overnight at $450^{\circ} \mathrm{C}$ ) $47 \mathrm{~mm}$ Whatman GF/F filters, which were subsequently dried. Samples for POC, PN, and $\delta^{13} \mathrm{C}_{\mathrm{POC}}$ were filtered on pre-combusted $25 \mathrm{~mm}$ Whatman GF/F filters and dried. These filters were later decarbonated with $\mathrm{HCl}$ fumes under partial vacuum for $4 \mathrm{~h}$, redried and packed in $\mathrm{Ag}$ cups. POC, $\mathrm{PN}$, and $\delta^{13} \mathrm{C}_{\mathrm{POC}}$ were determined on the EA-IRMS using the TCD signal of the EA to quantify POC and PN, and by monitoring $m / z, 44,45$, and 46 on the IRMS. Acetanilide was used as a standard for POC and PN, while sucrose (IAEA-C6) was used to calibrate the $\delta^{13} \mathrm{C}_{\mathrm{POC}}$ data. Reproducibility of $\delta^{13} \mathrm{C}_{\mathrm{POC}}$ measurements was better than $0.2 \%$ o. Samples for DOC and $\delta^{13} \mathrm{C}_{\mathrm{DOC}}$ were filtered as described above for nutrients, $40 \mathrm{~mL}$ of filtrate was preserved in glass vials with teflon-coated screw caps, by addition of $50-100 \mu \mathrm{L}$ of $\mathrm{H}_{3} \mathrm{PO}_{4}$. DOC and $\delta^{13} \mathrm{C}_{\mathrm{DOC}}$ were measured with an OI-1010 TOC analyser coupled to a Thermo DeltaPlus IRMS (see St-Jean, 2003; Osburn and St-Jean, 2007). Typical reproducibility was in the order of $<5 \%$ for DOC, and $\pm 0.2 \%$ of $\delta^{13} \mathrm{C}_{\mathrm{DOC}}$. To obtain sufficient amounts of suspended material for surface area measurements, $2-5 \mathrm{~L}$ of surface water was taken and pressurefiltered on $140 \mathrm{~mm}$ membrane filters $(0.45 \mu \mathrm{m})$ on some of the sampling sites on the main Tana River. These filters were wrapped up in cryotubes and immediately stored on liquid $\mathrm{N}_{2}$ until further processing in the laboratory.

Processing of organic carbon fractions for $\Delta^{14} \mathrm{C}$ was performed at the Royal Institute for Cultural Heritage (Brussels). After acidification with $\mathrm{H}_{3} \mathrm{PO}_{4}$, suspended 


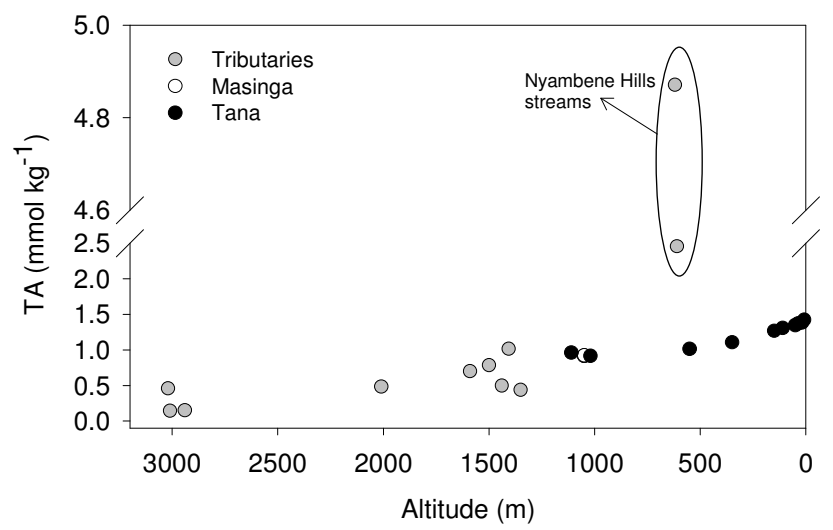

Fig. 2. Profile of total alkalinity (TA) in headwater streams, Masinga reservoir, and along the main Tana River. Note the break in Y-axis.

matter samples were combusted in quartz tubes with oxygen and copper oxide. The resulting $\mathrm{CO}_{2}$ was cryogenically purified in a vacuum extraction line, and graphitized and analyzed for ${ }^{14} \mathrm{C}$ at the Keck AMS facility (University of California). For DIC, $50-100 \mathrm{~mL}$ samples were acidified on the vacuum line using $\mathrm{H}_{3} \mathrm{PO}_{4}$ and the resulting $\mathrm{CO}_{2}$ was similarly purified and processed. All results have been corrected for isotopic fractionation according to the conventions of Stuiver and Polach (1977).

Surface area (SA) measurements of suspended matter were made on $200-600 \mathrm{mg}$ freeze-dried and homogenized samples, using multi-point BET (Braun-Emmet-Teller) adsorption isotherms. Measurements were made using a Quantachrome NOVA 3000 surface area analyser, and verified with BCR-173 (Institute for Reference Materials and Measurements). While organic matter is frequently removed prior to SA measurements, the data in Mayer (1994) indicate that this does not systematically affect SA data - hence, no further sample pretreatment was performed.

Samples for pigment analysis by HPLC were obtained by filtering a known volume of surface water on glass fibre filters $(0.7 \mu \mathrm{m}$, Whatman $\mathrm{GF} / \mathrm{F})$, immediately rolled up in cryotubes and stored in liquid $\mathrm{N}_{2}$. Upon return to the home laboratory, these were stored at $-80^{\circ} \mathrm{C}$ until analysis. Pigments were extracted in $10 \mathrm{~mL}$ acetone:water (90:10), and a subsample separated by HPLC on a C18 reverse phase column. Calibration was performed with working standards prepared from commercially available pure compounds.

Note that all data are also available as an electronic supplementary file http://www.biogeosciences.net/6/2475/2009/ bg-6-2475-2009-supplement.zip.

\section{Results}

\subsection{General physicochemical characteristics and nutri- ent concentrations}

Water temperature ranged from 11.7 to $31.8^{\circ} \mathrm{C}$, with a clear altitudinal gradient (Table 1), and with higher temperatures in surface waters of Masinga reservoir $\left(30.7 \pm 1.2^{\circ} \mathrm{C}\right) \mathrm{com}$ pared to the main Tana River just upstream and downstream of the reservoir $\left(\sim 24^{\circ} \mathrm{C}\right) \cdot \delta^{18} \mathrm{O}-\mathrm{H}_{2} \mathrm{O}$ signatures were relatively low in the headwater streams $(-5.6$ to $-4.1 \%$ ), and showed a gradual increase along the course of the Tana River, from $-3.5 \%$ oustream of Masinga reservoir to $-2.8 \%$ in the most downstream stations (Table 1). Consistent with the higher temperatures in Masinga reservoir, evaporation increased $\delta^{18} \mathrm{O}-\mathrm{H}_{2} \mathrm{O}$ signatures in its surface waters $(-3.1 \pm 0.1 \% \circ)$ compared to the Tana River upstream and downstream $(-3.5$ and $-3.4 \%$, respectively). $\mathrm{pH}$ values in tributaries ranged between 7.05 and 8.71, with an overall increase at higher altitudes (Table 1). $\mathrm{pH}$ in surface waters of Masinga reservoir were elevated $(8.24 \pm 0.06)$ compared to the Tana River upstream and downstream of the reservoir (7.76 and 7.22, respectively). Along the middle and lower Tana River (below $350 \mathrm{~m}$ ), pH was fairly stable at $8.19 \pm 0.04$, but decreased sharply in the most downstream sampling station in the delta (7.82).

In all stations, $\mathrm{NO}_{3}^{-}$was the dominant form (83-100\%) of dissolved inoraganic nitrogen (DIN). $\mathrm{NO}_{3}^{-}$concentrations showed a wide range in the different tributaries (1.9$64.9 \mu \mathrm{M})$ but were fairly stable along the main Tana River $(17.4 \pm 2.9 \mu \mathrm{M})$, the only marked pattern being a reduction of $>50 \%$ between pre-and post-Masinga Dam (Table 1). Surface waters of Masinga reservoir were extremely depleted in both $\mathrm{NO}_{3}^{-}(0.59 \pm 0.14 \mu \mathrm{M})$ and $\mathrm{NH}_{4}^{+}$(from $0.13 \mu \mathrm{M}$ at the most upstream location to undetectable levels near the reservoir outlet). As observed for nitrate, phosphate concentrations were highly variable in headwater streams $(0.13$ $4.60 \mu \mathrm{M})$ and highly depleted in surface waters of Masinga reservoir $(0.13 \pm 0.1 \mu \mathrm{M})$. Along the main Tana River, however, phosphate concentrations showed a very distinct (more than 20-fold) and consistent downstream increase, from $0.14 \mu \mathrm{M}$ below Masinga to $>3 \mu \mathrm{M}$ in the downstream part of the river (Table 1). As for $\mathrm{NO}_{3}^{-}$and phosphate, silicate concentrations varied widely in headwater streams (164$959 \mu \mathrm{M}$, with highest concentrations in streams draining the Nyambene Hills). Along the main Tana River, a major reduction was observed between pre- and post-Masinga reservoir (from 364 to $215 \mu \mathrm{M}$, i.e. a decrease of $41 \%$ ), and further downstream, silicate concentrations increased gradually but were stable at $310 \pm 4 \mu \mathrm{M}$ in the lower part of the river (below $150 \mathrm{~m}$ ). In surface waters of Masinga reservoir, silicate concentrations $(208 \pm 1 \mu \mathrm{M})$ were markedly lower than in the inflowing water $(364 \mu \mathrm{M})$. 

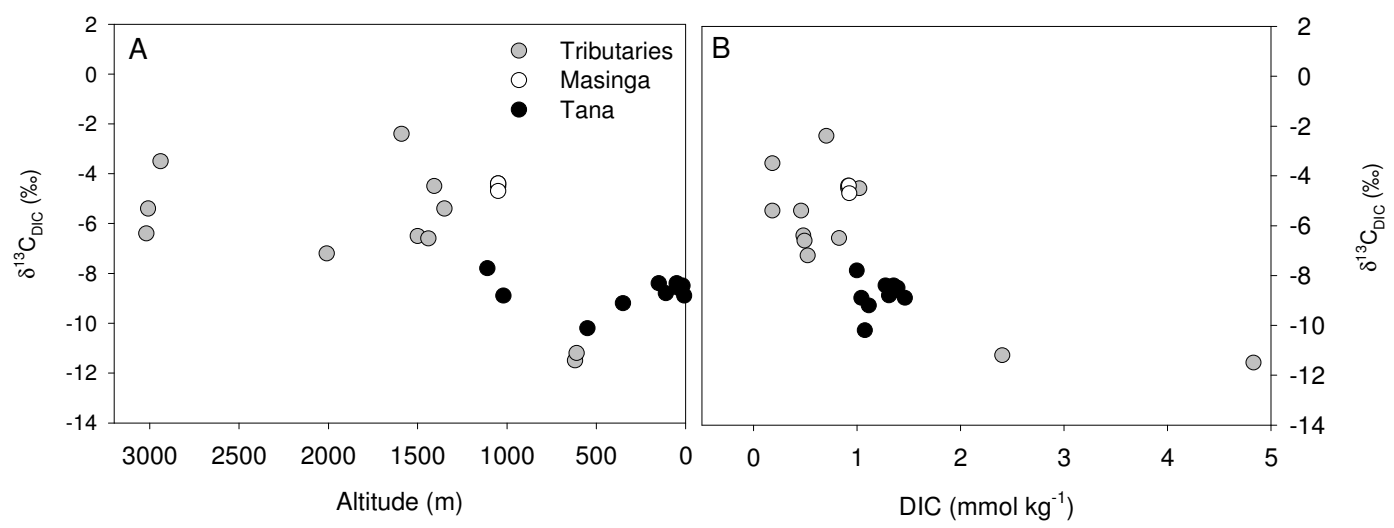

Fig. 3. (a) Profile of $\delta^{13} \mathrm{C}_{\mathrm{DIC}}$ in headwater streams, Masinga reservoir, and along the main Tana River, and (b) plot of DIC concentrations versus $\delta^{13} \mathrm{C}_{\text {DIC }}$.

\subsection{Total alkalinity, dissolved inorganic carbon, $\delta^{13} \mathbf{C}_{\text {DIC }}$ and $\Delta{ }^{14} \mathbf{C}_{\text {DIC }}$}

Headwater streams in the Aberdare range and on the slopes of Mt. Kenya were characterised by relatively low TA and DIC levels (0.181-1.022 mmol DIC kg-1), whereas the two streams draining the Nyambene Hills showed high TA and DIC levels (2.402 and $4.831 \mathrm{mmol} \mathrm{DIC} \mathrm{kg}^{-1}$, Fig. 2). With the exception of the two latter streams, there was a clear increase in TA and DIC with decreasing altitude, and DIC levels in the main Tana River increased gradually along the entire stretch of the river, from $0.997 \mathrm{mmol} \mathrm{kg}^{-1}$ above Masinga reservoir to $1.462 \mathrm{mmol} \mathrm{kg}^{-1}$ in the most downstream sampling site (Fig. 2). $\delta^{13} \mathrm{C}_{\text {DIC }}$ values ranged between -7.2 and $-2.4 \%$ in the Aberdare and Mt. Kenya streams, but were markedly lower in the (high-DIC) streams draining the Nyambene hills ( -11.5 to $-11.2 \%$ o Fig. 3). $\delta^{13} \mathrm{C}_{\text {DIC }}$ along the main Tana River ranged between $-7.8 \%$ o above Masinga reservoir to $-10.2 \%$. $\delta^{13} \mathrm{C}_{\mathrm{DIC}}$ was significantly higher in the surface waters of Masinga reservoir, ranging between -4.7 and $-4.4 \%$ (Fig. 3 ). $\Delta^{14} \mathrm{C}_{\mathrm{DIC}}$ were markedly more ${ }^{14} \mathrm{C}$-depleted compared to ${ }^{14} \mathrm{C}_{\mathrm{POC}}$ : one sample from Thuchi River (Mt. Kenya) had a $\Delta^{14} \mathrm{C}_{\text {DIC }}$ signature of $-658 \%$ o (i.e. $\sim 8600 \mathrm{yr}$ ), along the main Tana River the 5 available $\Delta{ }^{14} \mathrm{C}_{\mathrm{DIC}}$ data range from $+178 \%$ o (i.e., modern) upstream of Masinga reservoir to $-552 \%$ o (i.e. $\sim 6400 \mathrm{yr}$ ) at the most downstream sampling site, with an overall decrease in ${ }^{14} \mathrm{C}$ (Table 2).

$p \mathrm{CO}_{2}$ in headwater streams ranged between 110 and $1017 \mathrm{ppm}$ and showed no correlation with any of the other measured parameters (Fig. 4a). For the rivers on Mt. Kenya, there was a clear decreasing pattern in $p \mathrm{CO}_{2}$ along the E$\mathrm{W}$ gradient. $\quad p \mathrm{CO}_{2}$ in surface waters of Masinga reservoir were slightly under- or oversaturated (313-443 ppm) and decreased towards the downstream part of the reservoir. Along the Tana River, $p \mathrm{CO}_{2}$ was highest in the upper reaches, i.e. above (1085) and below Masinga reservoir (3570 and
Table 2. Overview of the available $\Delta{ }^{14} \mathrm{C}_{\mathrm{POC}}$ and $\Delta{ }^{14} \mathrm{C}_{\text {DIC }}$ data. n.d.: no data.

\begin{tabular}{|c|c|c|c|}
\hline Station & Location & $\begin{array}{r}\Delta{ }^{14} \mathrm{C}_{\mathrm{POC}} \\
(\% \circ)\end{array}$ & $\begin{array}{r}\Delta^{14} \mathrm{C}_{\text {DIC }} \\
(\% \circ)\end{array}$ \\
\hline \multicolumn{4}{|c|}{ Mount Kenya } \\
\hline 19 & Thuchi river & n.d. & -658 \\
\hline \multicolumn{4}{|c|}{ Main Tana River } \\
\hline 5 & $\begin{array}{l}\text { Sagana river, } \\
5 \mathrm{~km} \text { before Masinga Dam }\end{array}$ & n.d. & +178 \\
\hline 6 & $\begin{array}{l}\text { Tana River, } \\
\text { below Masinga Dam }\end{array}$ & n.d. & -198 \\
\hline 11 & $\begin{array}{l}\text { Tana River between } \\
\text { Masinga and Katse }\end{array}$ & -88 & n.d. \\
\hline 14 & $\begin{array}{l}\text { Tana River at Kora } \\
\text { National Park (Adamsons Falls) }\end{array}$ & -35 & -364 \\
\hline 20 & $\begin{array}{l}\text { Tana River, } \\
\text { Sankuri }\end{array}$ & -72 & n.d. \\
\hline 21 & $\begin{array}{l}\text { Tana River, } \\
\text { Nanigi }\end{array}$ & -100 & n.d. \\
\hline 22 & $\begin{array}{l}\text { Tana River, } \\
\text { Masalani }\end{array}$ & -89 & n.d. \\
\hline 23 & $\begin{array}{l}\text { Tana River, } \\
\text { Tana River primate reserve }\end{array}$ & -116 & -319 \\
\hline 25 & $\begin{array}{l}\text { Tana River } \\
\text { (Matombe branch), Chalaluma }\end{array}$ & -104 & -552 \\
\hline
\end{tabular}

$2170 \mathrm{ppm})$. Further downstream, $p \mathrm{CO}_{2}$ was relatively low and ranged typically between 500 and $660 \mathrm{ppm}$, increasing again in the delta $(1543 \mathrm{ppm})$. The latter would be consistent with earlier dry season data from the freshwater tidal estuary (4390 \pm 660 ppm, see Bouillon et al., 2007).

\subsection{Dissolved oxygen and $\delta^{18} \mathrm{O}-\mathrm{O}_{2}$}

Oxygen saturation levels $\left(\% \mathrm{O}_{2}\right)$ were generally close to or above saturation levels in most of the headwater streams (99-118\%), above saturation in surface waters of Masinga reservoir (108-114\%), and highly variable in the Tana River 

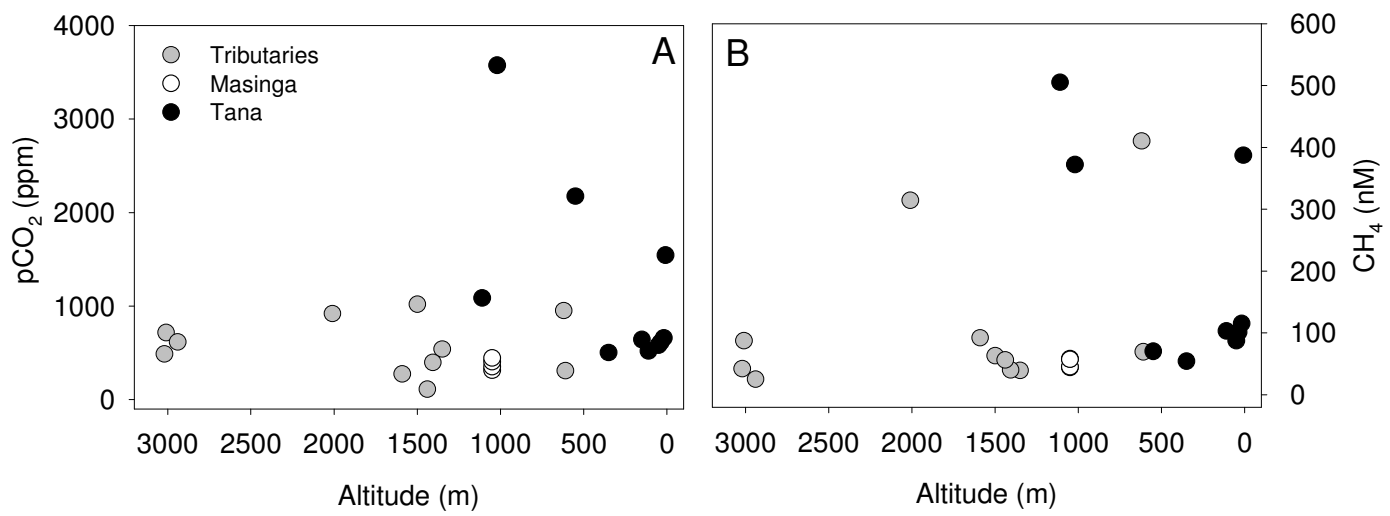

Fig. 4. Profiles of $p \mathrm{CO}_{2}$ in headwater streams, Masinga reservoir, and along the main Tana River.

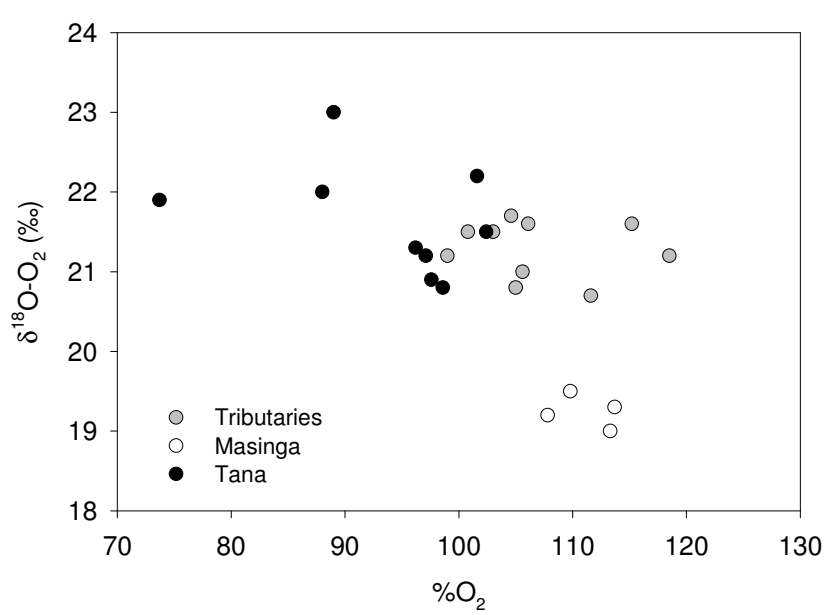

Fig. 5. Plot of available $\delta^{18} \mathrm{O}-\mathrm{O}_{2}$ signatures versus oxygen saturation levels for headwater streams, surface waters of Masinga reservoir, and the main Tana River. Note that data from 2 stations are not included since $\delta^{18} \mathrm{O}-\mathrm{O}_{2}$ data are missing.

(41-102\%, Fig. 5). In the latter, lowest $\% \mathrm{O}_{2}$ was observed just below Masinga reservoir. Throughout most of the lower Tana River, oxygen levels were slightly undersaturated, but decreased markedly in the lowest sampling site in the delta (74\%), consistent with the low $\% \mathrm{O}_{2}$ values recorded earlier in the freshwater end-member of the Tana estuary $(64 \pm 5 \%$, Bouillon et al., 2007). $\delta^{18} \mathrm{O}-\mathrm{O}_{2}$ values were consistently lower than the value expected for equilibrium with atmospheric $\mathrm{O}_{2}$ (i.e., $+24.2 \%$ ), and ranged between +19.0 and $+23.0 \%$ o (Fig. 5).

\subsection{Methane $\left(\mathrm{CH}_{4}\right)$}

$\mathrm{CH}_{4}$ concentrations (Fig. $4 \mathrm{~b}$ ) in headwater streams ranged typically between 25 and $92 \mathrm{nM}$, except for Muringato river $(314 \mathrm{nM})$ and Mutundu river $(410 \mathrm{nM})$. In the main Tana River, $\mathrm{CH}_{4}$ concentrations were relatively high upstream of Masinga reservoir ( $505 \mathrm{nM}$ ) but markedly lower below the reservoir $(372 \mathrm{nM})$. In the surface waters of the reservoir itself, $\mathrm{CH}_{4}$ concentrations were the lowest observed in this study $(51 \pm 7 \mathrm{nM})$. Along the middle and lower course, $\mathrm{CH}_{4}$ concentrations ranged between 54 and $387 \mathrm{nM}$, with the highest concentration observed in the Tana Delta (Fig. 4b). The observed $\mathrm{CH}_{4}$ concentrations consistently represent high levels of oversaturation, ranging from 850 to $21700 \%$.

\subsection{Suspended matter and aquatic organic carbon pools}

TSM concentrations were generally low in the perennial headwater streams $\left(0.6-25.4 \mathrm{mg} \mathrm{L}^{-1}\right.$, with one higher record of $86.2 \mathrm{mg} \mathrm{L}^{-1}$ in Muringato river), and in surface waters of Masinga reservoir $\left(2.3 \pm 0.3 \mathrm{mg} \mathrm{L}^{-1}\right)$. Along the main Tana River, TSM concentrations varied widely, from low values of 15.2 and $12.2 \mathrm{~m} \mathrm{~L}^{-1}$ before and after Masinga reservoir, respectively, increasing steadily to $483 \mathrm{mg} \mathrm{L}^{-1}$ in the most downstream sampling station (Fig. 6a). POC concentrations showed a similar altitudinal pattern (Fig. 6b), although the increase was less pronounced than for TSM, resulting in a decreasing altitudinal gradient in \%POC/TSM (Fig. 7). Along the main Tana River, \%POC/TSM decreased from $4.6 \%$ after Masinga reservoir to $\sim 1.1 \%$ in the most downstream sampling stations. For surface waters of Masinga reservoir, however, high \%POC/TSM (32.6 $\pm 3.6 \%)$ diverge from this pattern (Fig. 7) because particulate matter there was predominantly composed of phytoplankton (see below). POC/PN ratios in suspended matter ranged between 8.2 and 18.5. DOC concentrations ranged between 0.3 and $2.5 \mathrm{mg} \mathrm{L}^{-1}$, with the majority of data in a fairly narrow range between 0.6 and $1.2 \mathrm{mg} \mathrm{L}^{-1}$ (Fig. 8a). DOC/POC ratios (Fig. 8b) were higher in high-altitude $(\sim 3000 \mathrm{~m})$ tributaries $(1.9 \pm 0.2)$ than in the tributaries draining Mt. Kenya and Nyambene Hills at lower altitude $(0.8 \pm 0.3)$. Along the Tana River, DOC/POC ratios declined from $\sim 1.6$ in the vicinity of Masinga reservoir to 0.2 along the lower Tana River (Fig. 8b). DOC/POC ratios were inversely related to the logarithm of TSM concentrations, but with a different relationship for tributaries and the main Tana River course (Fig. 8c). 


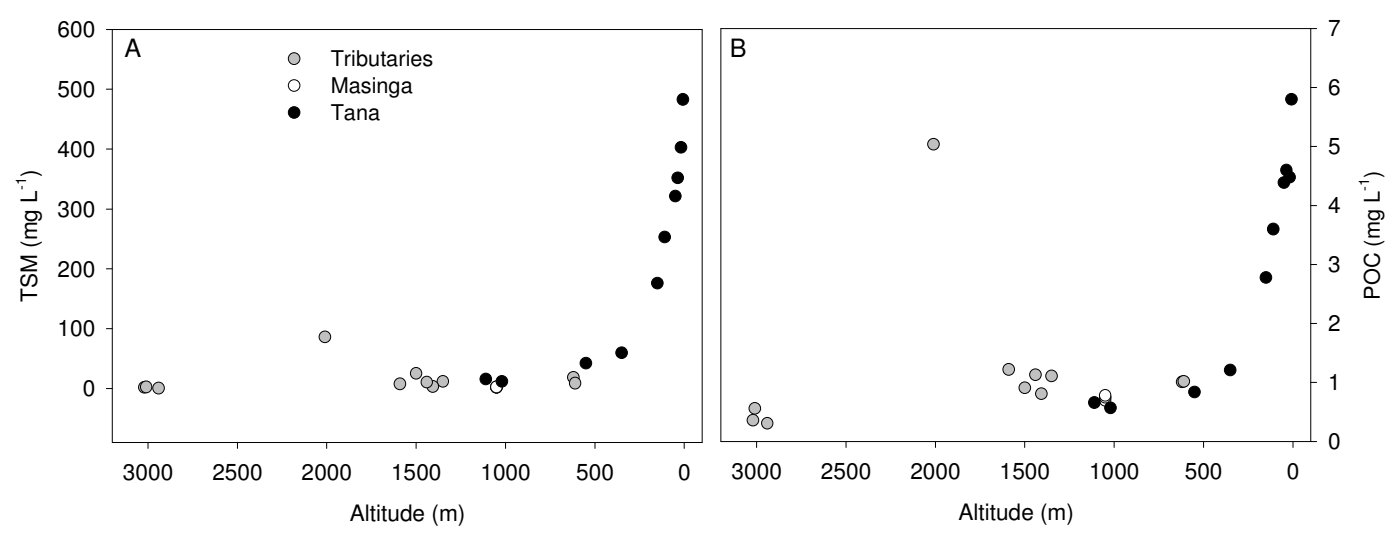

Fig. 6. Profiles of (a) total suspended matter concentrations, and (b) particulate organic carbon concentrations in headwater streams, Masinga reservoir, and along the main Tana River.

The specific surface areas (SA) measured on 5 of the Tana River suspended matter samples from the lower river are very high (63.6-82.2 $\left.\mathrm{m}^{2} \mathrm{~g}^{-1}\right)$ compared to values reported for coastal sediments, estuaries and rivers (typically $\left.<50 \mathrm{~m}^{2} \mathrm{~g}^{-1}\right)$, and OC:SA ratios found here $(0.16-$ $0.22 \mathrm{mg} \mathrm{C} \mathrm{m}^{-2}$ ) are consequently in the lower range of those reported in the literature (e.g., Keil et al., 1997; Aufdenkampe et al., 2007). The SA values in suspended matter are also consistently higher than those observed in surface soils which ranged between 11.8 and $67.7 \mathrm{~m}^{2} \mathrm{~g}^{-1}$ (data not shown).

\subsection{Carbon sources in dissolved and suspended particu- late organic carbon: stable and radiocarbon isotope signatures}

$\delta^{13} \mathrm{C}$ signatures of suspended POC (Fig. 9a) varied between -26.5 and $-22.7 \%$ o for the various tributaries, and between -25.2 and $-21.2 \%$ along the main Tana River. In surface waters of Masinga reservoir, $\delta^{13} \mathrm{C}_{\mathrm{POC}}$ was markedly more depleted, with an average signature of $-29.0 \pm 0.3 \%$. $\delta^{13} \mathrm{C}_{\mathrm{DOC}}$ ranged between -27.7 and $-21.8 \%$ in tributaries, within a narrow range of between -24.0 and $-22.7 \%$ along the Tana River, and in contrast to POC, did not show a marked depletion in ${ }^{13} \mathrm{C}$ in surface waters of Masinga reservoir, with an average $\delta^{13} \mathrm{C}$ of $-23.9 \pm 0.3 \%$ (Fig. 9b). Overall, $\delta^{13} \mathrm{C}_{\mathrm{DOC}}$ and $\delta^{13} \mathrm{C}_{\mathrm{POC}}$ were clearly uncoupled, showing a relatively weak relationship (Fig. 9c). $\Delta^{14} \mathrm{C}$ data are available for a selected number of POC samples from the main Tana River and ranged between -116 and $-35 \%$, corresponding to an estimated age of $\sim 935$ and 230 years. $\Delta^{14} \mathrm{C}_{\mathrm{POC}}$ showed a general decrease along the lower Tana River, which coincides with the overall decrease in $\%$ POC/TSM in suspended matter (Fig. 10).

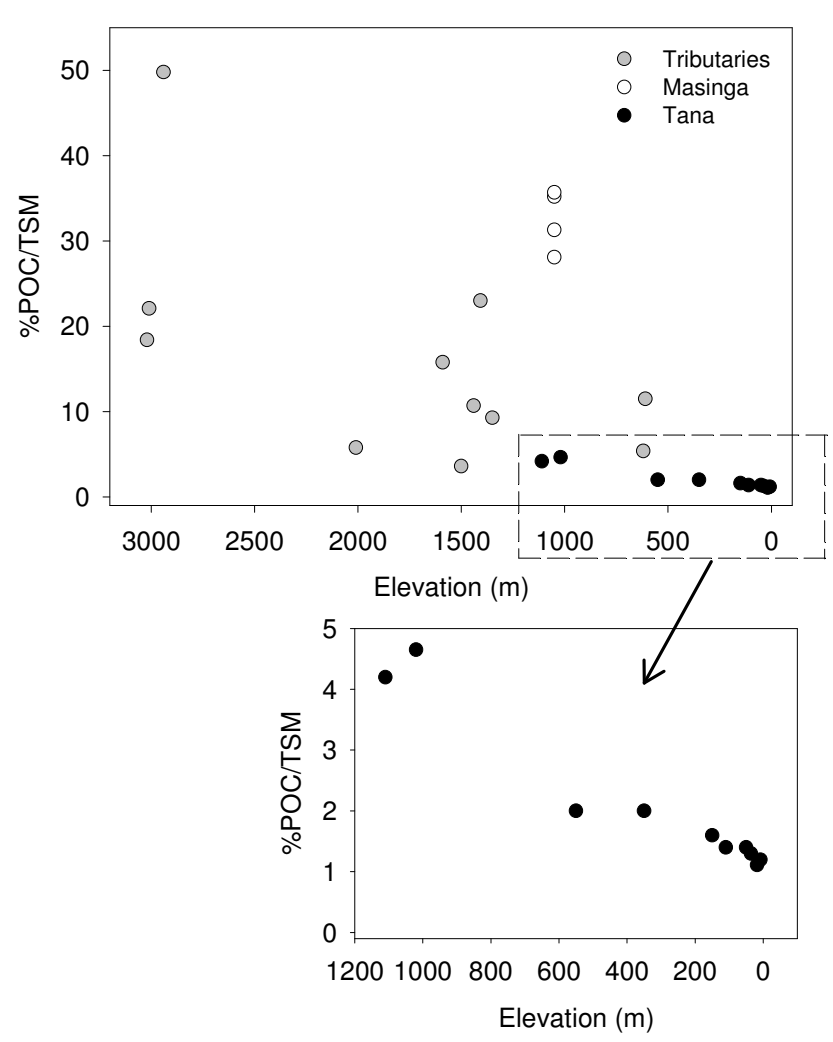

Fig. 7. Profile of \%POC/TSM in headwater streams, Masinga reservoir, and along the main Tana River. Lower panel shows enlargement for data on the main Tana River.

\subsection{Pigment concentrations}

Chl- $a$ concentrations averaged $0.91 \pm 0.21 \mu \mathrm{gL}^{-1}$ in the streams draining Mt. Kenya, were about twice as high $(1.75 \pm 0.08)$ in the streams draining the Nyambene Hills, and increased from $\sim 0.80 \mu \mathrm{g} \mathrm{L}^{-1}$ in the upper Tana River to values between 5.23 and $6.96 \mu \mathrm{g} \mathrm{L}^{-1}$ in the lower Tana 

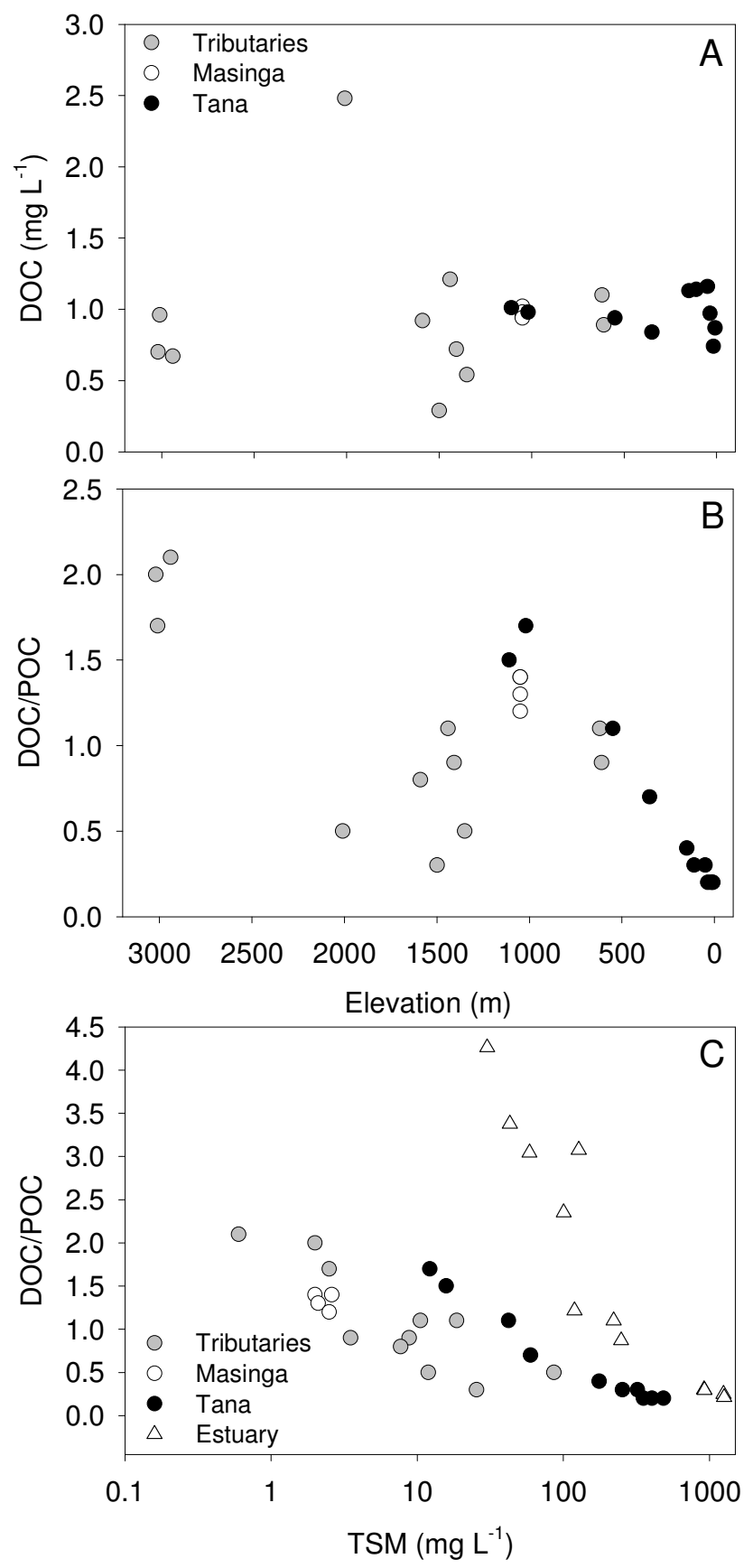

Fig. 8. Profiles of (a) DOC, and (b) DOC/POC ratios, and (c) plot of DOC/POC ratios versus TSM concentrations (log scale) in headwater streams, Masinga reservoir, and along the main Tana River. In panel (c), data from the freshwater and oligohaline zone of the Tana estuary (from Bouillon et al., 2007) are included for comparison.

River (Fig. 11a, note that no pigment data are available for the streams in the Aberdare range). In Masinga reservoir, chl- $a$ concentrations were high $\left(3.23-5.08 \mu \mathrm{g} \mathrm{L}^{-1}\right)$ compared to the Tana River before and after the reservoir. The resulting POC/chl- $a$ ratios (Fig. 11b) were relatively high
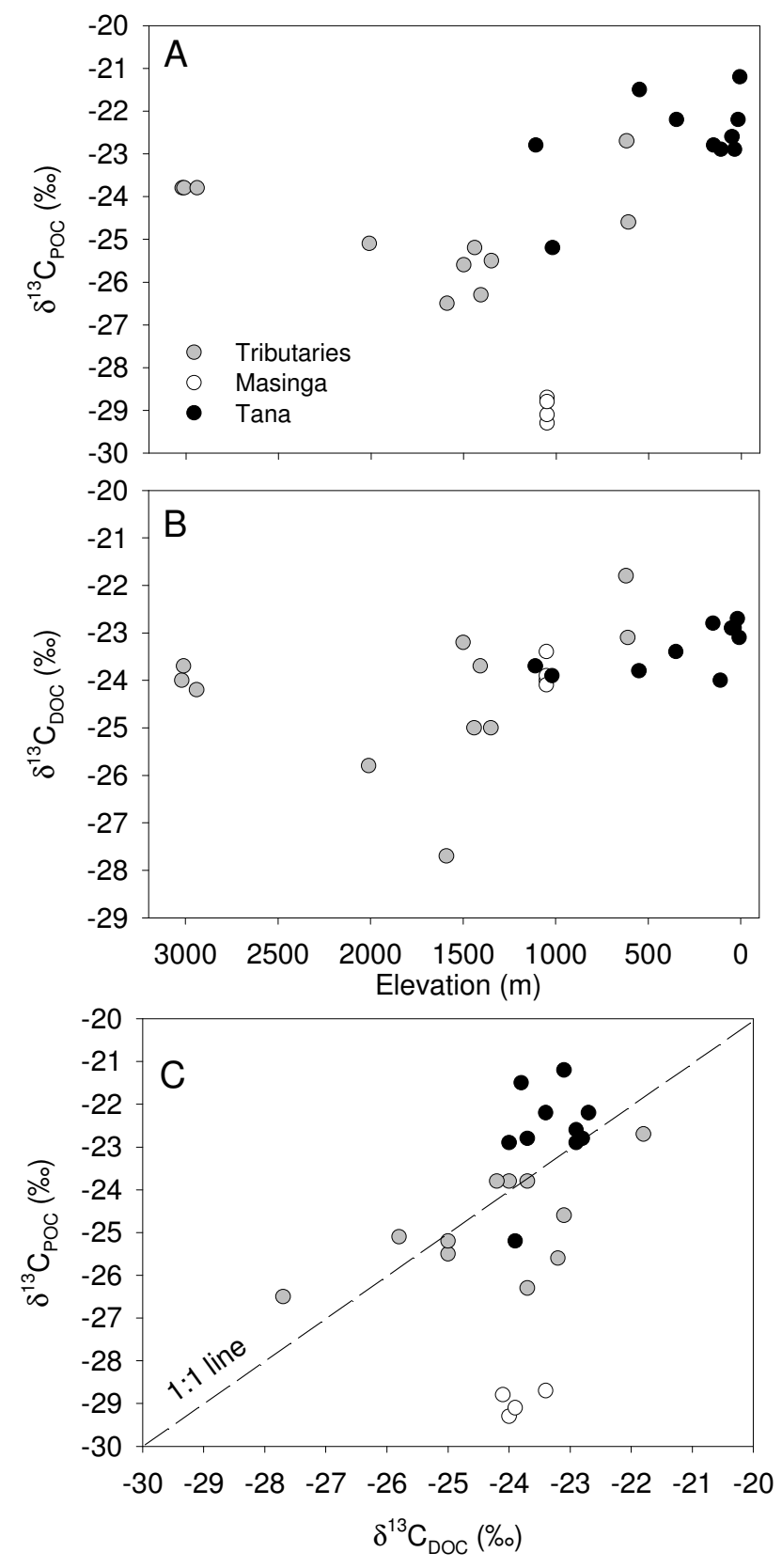

Fig. 9. Profiles of (a) $\delta^{13} \mathrm{C}$ signatures in POC, (b) $\delta^{13} \mathrm{C}$ signatures in DOC; and (c) plot of $\delta^{13} \mathrm{C}$ signatures of DOC versus those of POC in headwater streams, Masinga reservoir, and along the main Tana River.

in the Mt. Kenya and Nyambene Hill streams $(1156 \pm 129$ and $580 \pm 31$, respectively), and low in the surface waters of Masinga reservoir (206 \pm 35 ). Along the Tana River, POC/chl- $a$ ratios showed no clear gradient but were relatively high overall (570-2081, average of 934 \pm 472 ). Chl$b$, indicative of green algae, was detected in most sampling sites, in particular in the lower Tana River $\left(>500 \mu \mathrm{g} \mathrm{L}^{-1}\right.$, but $<200 \mu \mathrm{g} \mathrm{L}^{-1}$ in other sites). The cyanobacterial pigment 


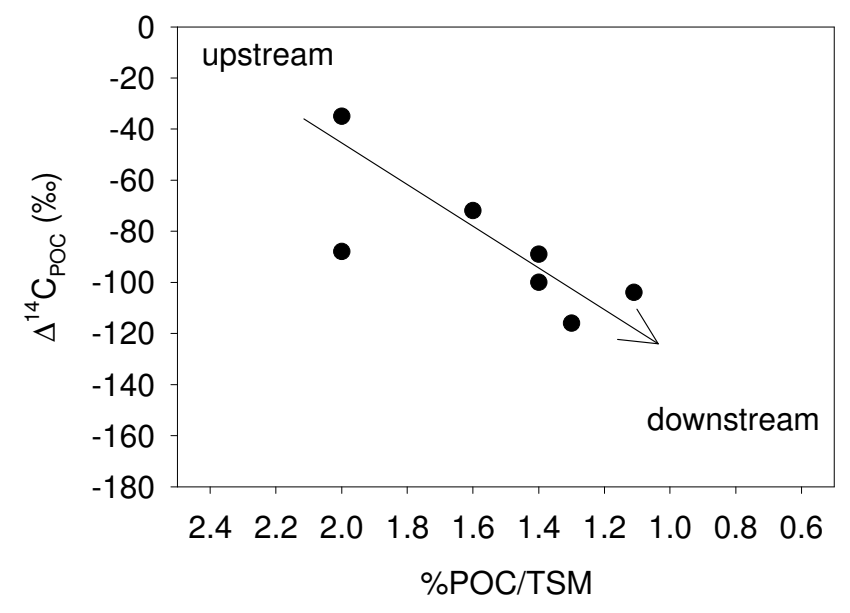

Fig. 10. Covariation between \%POC/TSM and radiocarbon composition of POC along the main Tana River.

echinenone was only detected in Masinga reservoir $(0.15-$ $\left.0.29 \mu \mathrm{g} \mathrm{L}^{-1}\right)$, and was absent in all other sites. Zeaxanthin (another cyanobacterial marker, but which can also be present in diatoms) was more widespread, but highest concentrations in Masinga reservoir (0.29-0.39 $\mu \mathrm{g} \mathrm{L}^{-1}$, compared to $0-0.25 \mu \mathrm{g} \mathrm{L}^{-1}$ elsewhere). Alloxanthin, which is very specific to cryptophytes, was present in surface waters of Masinga $\left(0.14 \pm 0.06 \mu \mathrm{g} \mathrm{L}^{-1}\right)$ and in the Tana River sites just upstream and downstream of Masinga reservoir, but absent in all other samples.

\section{Discussion}

\subsection{General physico-chemistry and nutrient concentra- tions, and the effects of Masinga Reservoir}

Given the large altitudinal gradient covered in this survey, water temperatures ranged widely from as low as $11.7^{\circ} \mathrm{C}$ in some upper headwater streams to $\sim 30^{\circ} \mathrm{C}$ in the lower Tana River, and high temperatures in surface waters of Masinga Reservoir (Table 1). The longer residence time in Masinga reservoir ( $\sim 3$ months) induced a local increase in $\delta^{18} \mathrm{O}-\mathrm{H}_{2} \mathrm{O}$ in its surface waters $(-3.1 \pm 0.1 \%$ o, compared to -3.5 and $-3.4 \%$ upstream and downstream) due to evaporation. The associated primary production (see below) also increased the $\mathrm{pH}$ in surface waters of Masinga reservoir (8.24 \pm 0.06$)$ compared to the Tana River upstream and downstream of the reservoir (7.76 and 7.22, respectively). $\mathrm{pH}$ also increased further down the Tana River (with an average of $8.19 \pm 0.04$ below $350 \mathrm{~m}$ ), but decreased sharply near the Tana delta (7.82), consistent with the lower values reported earlier in the freshwater end of the estuary during the end of the dry season in 2004 (7.41-7.51, see Bouillon et al., 2007).

The elevated water residence time in Masinga reservoir and associated biological processes were responsible for a

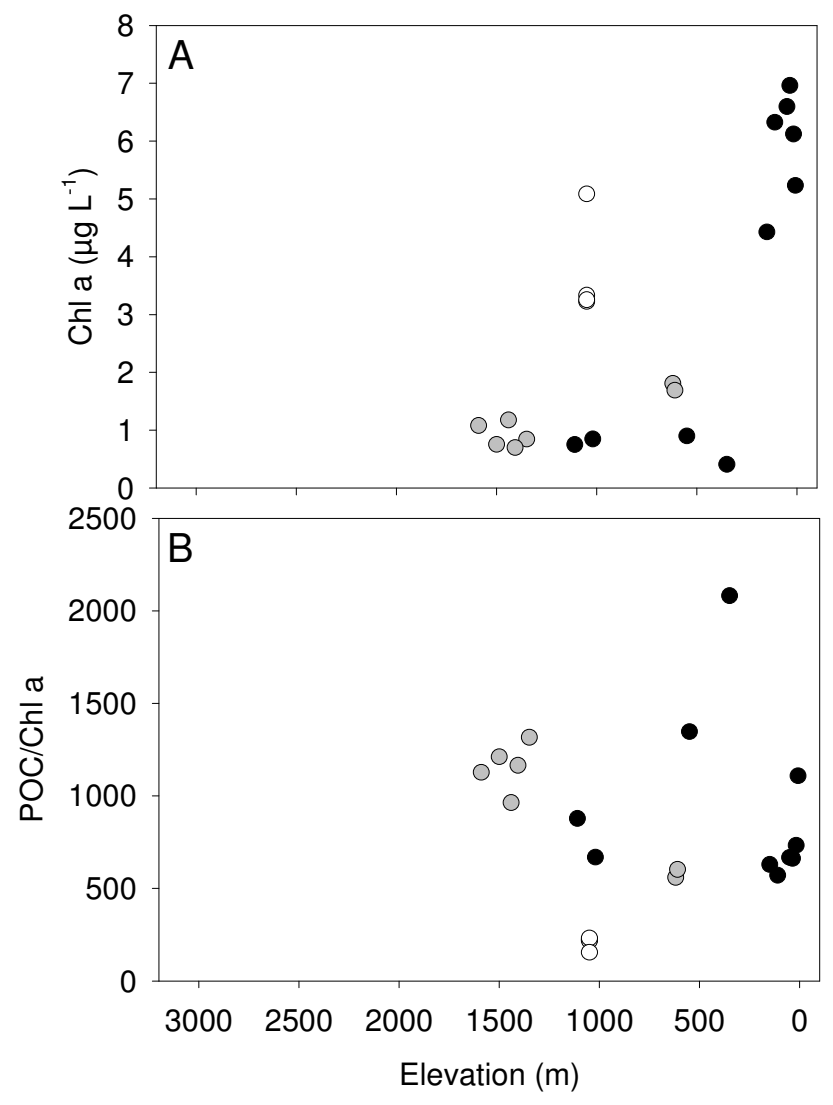

Fig. 11. Profiles of (a) chl- $a$, and (b) POC/chl- $a$ ratios in headwater streams, Masinga reservoir, and along the main Tana River. Note that no data are available for streams draining the Aberdares, but the $\mathrm{X}$-axis scale is similar to that of other profile plots for easier comparison.

major reduction in DIN (Tables 1 and 3). Surface waters of Masinga reservoir were extremely depleted in both $\mathrm{NO}_{3}^{-}$and $\mathrm{NH}_{4}^{+}$, and the overall relative decrease in concentrations between the main inlet and the outlet of the reservoir was 53 and $55 \%$ for $\mathrm{NO}_{3}^{-}$and $\mathrm{NH}_{4}^{+}$, respectively (Table 3 ). The recent review by Harrison et al. (2009) confirms the importance of reservoirs on $\mathrm{N}$ retention, and estimates that these systems are responsible to up to $33 \%$ of the global $\mathrm{N}$ removal from lentic ecosystems (i.e. lakes and reservoirs), despite their relatively small areal extent. As observed for DIN, dissolved phosphate was highly depleted in surface waters of Masinga reservoir, with an overall reduction in phosphate between the main inflow and outflow of the reservoir of $72 \%$ (Table 3 ). Along the main Tana River, however, phosphate concentrations strongly increased more than 20-fold downstream (Table 1). Phosphorus dynamics in aquatic systems are often to a large extent determined by interactions with suspended particles. Bound P associated with sediment particles (generally through adsorption on $\mathrm{Fe}$ or $\mathrm{Al}$ oxides) reversibly exchanges with the dissolved phase (Fox, 1989; Fox et al., 1986). Major processes responsible for release of particle-bound $\mathrm{P}$ include 
Table 3. Comparison of selected biogeochemical parameters on the Tana River upstream and downstream of Masinga reservoir, and in surface waters of Masinga (for the latter, $n=4$ ).

\begin{tabular}{|c|c|c|c|}
\hline & $\begin{array}{r}\text { above } \\
\text { reservoir }\end{array}$ & $\begin{array}{r}\text { Masinga } \\
\text { surface water }\end{array}$ & $\begin{array}{l}\text { Tana River, } \\
\text { below dam }\end{array}$ \\
\hline$\% \mathrm{O}_{2}$ & 88 & $111 \pm 3$ & 41 \\
\hline $\mathrm{pH}^{2}$ & 7.76 & $8.24 \pm 0.06$ & 7.22 \\
\hline $\mathrm{NH}_{4}^{+}(\mu \mathrm{M})$ & 1.39 & $0.08 \pm 0.06$ & 0.62 \\
\hline $\mathrm{NO}_{3}^{-}(\mu \mathrm{M})$ & 20.6 & $0.59 \pm 0.14$ & 9.6 \\
\hline $\mathrm{PO}_{4}^{+}(\mu \mathrm{M})$ & 0.50 & $0.13 \pm 0.01$ & 0.14 \\
\hline $\mathrm{SiO}_{2}(\mu \mathrm{M})$ & 364 & $208 \pm 1$ & 215 \\
\hline $\mathrm{TSM}\left(\mathrm{mg} \mathrm{L}^{-1}\right)$ & 15.8 & $2.3 \pm 0.3$ & 12.2 \\
\hline$\delta^{13} \mathrm{C}-\mathrm{POC}(\% \circ)$ & -22.8 & $-29.0 \pm 0.3$ & -25.2 \\
\hline$\delta^{13} \mathrm{C}-\mathrm{DOC}(\% o)$ & -23.7 & $-23.9 \pm 0.3$ & -23.9 \\
\hline $\operatorname{DOC}\left(\mathrm{mg} \mathrm{L}^{-1}\right)$ & 1.01 & $0.97 \pm 0.04$ & 0.98 \\
\hline$\%$ POC/TSM & 4.2 & $32.6 \pm 3.6$ & 4.6 \\
\hline$p \mathrm{CO}_{2}(\mathrm{ppm})$ & 1085 & $378 \pm 57$ & 3572 \\
\hline $\mathrm{CH}_{4}(\mathrm{nM})$ & 505 & $51 \pm 7$ & 372 \\
\hline$\delta^{18} \mathrm{O}-\mathrm{DO}$ & +22.0 & $+19.2 \pm 0.2$ & n.d. \\
\hline$\delta^{18} \mathrm{O}-\mathrm{H}_{2} \mathrm{O}$ & -3.5 & $-3.1 \pm 0.1$ & -3.4 \\
\hline$\delta^{13} \mathrm{C}-\mathrm{DIC}$ & -7.8 & $-4.5 \pm 0.1$ & -8.9 \\
\hline
\end{tabular}

(i) changes in the aquatic chemistry, whereby a significant fraction of particle-associated $\mathrm{P}$ can be released into the water column due to competition with other anions (Deborde et al., 2008 and references therein), and (ii) resuspension of sediments, likely due to reduction of $\mathrm{Fe} / \mathrm{Al}$ oxides under the anoxic conditions during storage in bottom sediments (Evans et al., 2004, and references therein). The large and steady increase in phosphate observed here along the middle and lower Tana River matches very well with the concurrent increase in TSM concentrations (Fig. 6), which strongly suggests that phosphate concentrations are indeed mainly governed by dynamic exchange equilibria between dissolved $\mathrm{P}$ and particle-associated $\mathrm{P}$.

Highest dissolved silicate concentrations were found in streams draining the Nyambene Hills. The latter region is lithologically distinct from the other headwater regions in being partly dominated by Quaternary volcanic rocks rather than Precambian or Tertiary volcanic rocks (King and Chapman, 1972), and by its distinctively higher soil carbonate equivalent (World Soil and Terrain Database, SOTER, accessible through www.isric.org). This difference in parent material and the likely lower soil thickness covering it can be expected to result in higher weathering rates of $\mathrm{Si}$ and other elements (Heimsath et al., 1997). In line with this, the 2 streams sampled in this area also have markedly higher concentrations of $\mathrm{K}, \mathrm{Ca}, \mathrm{Mg}, \mathrm{Na}$ (data not shown) and total alkalinity (Fig. 2) than the headwater streams draining the Aberdares and Mt. Kenya.

A major reduction between pre- and post-Masinga reservoir was also observed for silicate (from 364 to $215 \mu \mathrm{M}$, i.e. a decrease of $41 \%$, Table 3). Consistent with this large reduction in dissolved $\mathrm{Si}$, the phytoplankton composition in Masinga reservoir has been found to consist predominantly of the diatom genus Nitzschia (Uku and Mavuti, 1994). However, for both silicate and phosphate the concentrations in the outflow (Table 3 ) were only slightly higher than in surface waters, whereas for both $\mathrm{NO}_{3}^{-}$and $\mathrm{NH}_{4}^{+}$, the outflowing water had concentrations about $\sim 50 \%$ of those in the inflowing Tana River, i.e. much higher than in surface waters of the reservoir (Table 3). As the outflow of the reservoir is located near the bottom (Piésold et al., 1985), this indicates that DIN is partly regenerated in the (likely anoxic) bottom waters, while $\mathrm{Si}$ and phosphate are not.

\subsection{Inorganic carbon and dissolved oxygen dynamics}

$p \mathrm{CO}_{2}$ values in headwater streams varied widely (110$1017 \mathrm{ppm}$; Fig. 4a) and could not be correlated to other biogeochemical characteristics. Surface waters of Masinga reservoir were slightly under- or oversaturated in $\mathrm{CO}_{2}\left(p \mathrm{CO}_{2}\right.$ ranging from 313-443 ppm) and decreased towards the outflow of the reservoir. Even along the main Tana River, $p \mathrm{CO}_{2}$ was relatively low, ranging typically between 500 and $660 \mathrm{ppm}$ along the lower course of the river, with the exception of the outflow of Masinga reservoir $(<3000 \mathrm{ppm})$ and towards the tidal floodplains in the delta (1543 ppm). Mirroring the relatively low $p \mathrm{CO}_{2}$ data, the relatively high oxygen saturation levels in the tributaries $(99-119 \%)$ and low $\delta^{18} \mathrm{O}-$ $\mathrm{O}_{2}$ values (all $<+24.2 \%$ o), suggest substantial contributions of $\mathrm{O}_{2}$ produced by in situ primary production (which has the same $\delta^{18} \mathrm{O}$ signature as that of the water, i.e. ranging between -5.6 and $-4.1 \%$ o for the tributaries). A clear negative correlation between $\delta^{18} \mathrm{O}-\mathrm{O}_{2}$ and $\% \mathrm{O}_{2}$ is evident for the data from the main Tana River and Masinga reservoir (Fig. 5), as expected based on isotope fractionation during respiration (i.e. remaining $\mathrm{O}_{2}$ becomes enriched in ${ }^{18} \mathrm{O}$ ) and photosynthetic $\mathrm{O}_{2}$ inputs (which increases $\% \mathrm{O}_{2}$ and decreases $\delta^{18} \mathrm{O}$ $\mathrm{O}_{2}$, due to inputs of $\mathrm{O}_{2}$ with a signature similar to that of the source $\mathrm{H}_{2} \mathrm{O}$, see Guy et al. (1993)). In contrast, the data from the headwater streams do not show a clear relationship between $\% \mathrm{O}_{2}$ and $\delta^{18} \mathrm{O}-\mathrm{O}_{2}$ (Fig. 5), suggesting that other processes besides pelagic photosynthesis and pelagic respiration are significant in influencing $\mathrm{O}_{2}$ dynamics (e.g. benthic $\mathrm{O}_{2}$ consumption which is accompanied with little fractionation (Brandes and Devol, 1997). Data on $\% \mathrm{O}_{2}$ and $\delta^{18} \mathrm{O}-\mathrm{O}_{2}$ data can be used to estimate the ratio of primary production to respiration (P:R) in freshwater systems (Quay et al., 1995) when steady state conditions apply, i.e., when no significant diurnal variations in $\% \mathrm{O}_{2}$ and $\delta^{18} \mathrm{O}-\mathrm{O}_{2}$ occur. When steady-state assumptions are not met, such as in highly productive shallowwater ecosystems, this approach may introduce a significant bias in estimated P:R ratios (e.g., Tobias et al., 2007), but for Masinga reservoir and the lower Tana River, we believe this approach offers a reasonable first estimate. Resulting P:R estimates range from 1.1 to 1.3 for Masinga reservoir and 
between 0.76 and 1.08 for the main Tana River. Although the assumption of steady-state conditions can not be verified in the absence of data on diurnal variations, the clear negative correlation between P:R estimates and $p \mathrm{CO}_{2}$ data $\left(R^{2}=0.89\right.$ for an inverse first order fit, data not shown) suggests that our approach provides a relative indication of $P: R$ in this system. In conclusion, although direct metabolic process rates are currently unavailable for any of the sampling sites, the combination of pigment concentrations and indirect indicators of aquatic metabolism $\left(p \mathrm{CO}_{2}, \% \mathrm{O}_{2}, \delta^{18} \mathrm{O}-\mathrm{O}_{2}\right)$ all suggest that in situ primary production cannot be ignored as a potential contributor to carbon sources in the system - even in the highly turbid lower Tana River.

\subsection{Isotope contraints on inorganic carbon origin and cycling}

Considering all sampling sites, $\delta^{13} \mathrm{C}_{\mathrm{DIC}}$ was negatively correlated with DIC concentrations, i.e. highest DIC concentrations were associated with lowest $\delta^{13} \mathrm{C}_{\text {DIC }}$ (Fig. 3b). Highaltitude streams in the Aberdares and on Mt. Kenya had low DIC concentrations and relatively high $\delta^{13} \mathrm{C}_{\mathrm{DIC}}$, while those draining the lower Nyambene Hills show remarkably high DIC concentrations and much lower $\delta^{13} \mathrm{C}_{\text {DIC }}$; samples from the main Tana River are intermediate between these signatures (Fig. 3b). A largely similar pattern was observed in the Rhône basin (France) by Aucour et al. (1999), where upstream (Alpine) tributaries showed lower DIC and more enriched $\delta^{13} C_{D I C}$ values, while lowland tributaries showed higher DIC and lower $\delta^{13} C_{\text {DIC }}$. Aucour et al. (1999) attributed this trend to a dominance of carbonate weathering with biogenic $\mathrm{CO}_{2}$ as the DIC source in their lowland tributaries, while they suggested that carbonate dissolution with atmospheric $\mathrm{CO}_{2}$ and/or organic/sulfuric acids dominated in the higher altitude tributaries. In our dataset, however, we found $\delta^{13} \mathrm{C}_{\text {DIC }}$ to be negatively correlated with both $\mathrm{Ca}^{2+}$ and silicate concentrations in the headwater streams, and DIC concentrations are well correlated with both $\mathrm{Ca}^{2+}$ and $\mathrm{Si}$ concentrations. Silicate weathering results in a DIC pool with a $\delta^{13} \mathrm{C}$ signature expected to range between -18 and $-5 \%$ (for C3- and C4-dominated sites, respectively), i.e., similar to that of the organic matter remineralized within the soil but taking into account additional fractionation during diffusion of $\mathrm{CO}_{2}$ into the soil water phase (see Brunet et al., 2005). A further enrichment in ${ }^{13} \mathrm{C}$ can be expected in these relatively shallow tributaries due to atmospheric exchange (e.g., Doctor et al., 2008). Streamwater DIC from atmospheric inputs or carbonate mineral dissolution by biogenic $\mathrm{CO}_{2}$ would result in more enriched $\delta^{13} \mathrm{C}$ signatures $(\sim-12$ to $-2 \%$ ), since DIC produced by carbonate dissolution is composed of equal fractions of soil $\mathrm{CO}_{2}\left(\delta^{13} \mathrm{C}\right.$ depending on $\mathrm{C} 3 / \mathrm{C} 4$ abundance, $\Delta{ }^{14} \mathrm{C}$ variable) and carbonates $\left(\delta^{13} \mathrm{C} \sim 0 \%\right.$ and ${ }^{14} \mathrm{C}$-free assuming ancient marine carbonates). Thus, a further contrast between silicate weathering and carbonate weathering can be expected in the resulting

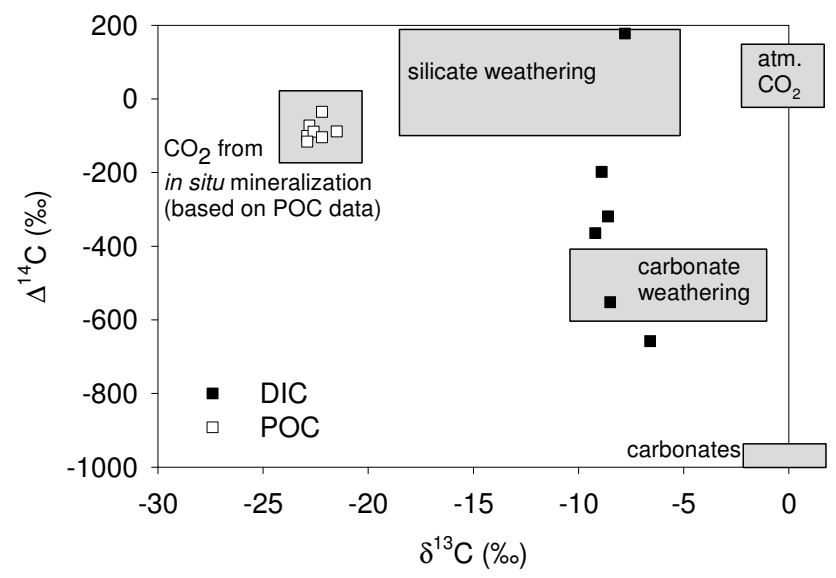

Fig. 12. Plot of $\delta^{13} \mathrm{C}$ and $\Delta^{14} \mathrm{C}$ signatures in DIC observed in this study, along with representative signatures of potential DIC sources. $\delta^{13} \mathrm{C}$ and $\Delta^{14} \mathrm{C}$ signatures of POC are also plotted to indicate the expected signatures for $\mathrm{CO}_{2}$ produced by in situ remineralization.

$\Delta^{14} \mathrm{C}$-DIC signatures, which are much more ${ }^{14} \mathrm{C}$-depleted in the case of carbonate weathering (Fig. 12).

Radiocarbon data on DIC from our survey (Table 2, Fig. 12) vary from contemporary values upstream of Masinga reservoir to very depleted (i.e. old) values further downstream, and highly depleted values in one of the tributaries draining Mt. Kenya $(-658 \%$ ) and in the Tana Delta $(-552 \%$ ). The latter two values are even lower then would be expected based on carbonate dissolution by biogeonic $\mathrm{CO}_{2}$ (i.e., intermediate between ${ }^{14} \mathrm{C}$-free carbonates and organic matter), and alternative DIC sources must therefore be invoked. Two potential sources include (i) metamorphic $\mathrm{CO}_{2}$, which is a plausible source in volcanic areas such as the Mt. Kenya tributary, (e.g., see Evans et al. (2008) and Gaillarded and Galy (2008)), and (ii) direct carbonate dissolution by organic or sulfuric acids. The latter would appear the most likely explanation for the ${ }^{14} \mathrm{C}$-depleted DIC signature observed in the Tana delta.

For the main Tana River, the $\Delta{ }^{14} C_{\text {DIC }}$ values are relatively low compared to data from most other large river basins (e.g., Mayorga et al., 2005), but similarly low $\Delta^{14} C_{\text {DIC }}$ data have been reported from the Strickland river (Papua New Guinea, see Alin et al., 2007) and are more typical of higer-altitude streams (see references in Alin et al., 2007) due to e.g. contributions by carbonate weathering or groundwater contributions. In-stream production of DIC along this stretch of the river does not appear to be significant in the overall DIC transported downstream: the DIC inputs from respiration are expected to similar to those of POC $\left(\delta^{13} \mathrm{C} \sim-22 \%\right.$ o, $\Delta{ }^{14} \mathrm{C}$ between -40 and $-120 \%$ ) which would result in an opposite downstream trend as that observed (Table 2). Our combined $\delta^{13} \mathrm{C}$ and $\Delta^{14} \mathrm{C}$ data thus suggest that alkalinity in the Tana headwater streams results from a variable combination of both silicate and carbonate weathering inputs, and 
stress the role of these processes in setting baseline $\delta^{13} \mathrm{C}_{\mathrm{DIC}}$ across a range of settings. Finally, an important implication for these low $\Delta^{14} C_{\text {DIC }}$ values for future radiocarbon studies in this system is that in-situ primary production in the lower Tana River will also be characterized by low $\Delta{ }^{14} \mathrm{C}_{\mathrm{POC}}$ values, i.e. that recent phytoplankton production is likely to have an "old" ${ }^{14} \mathrm{C}$ age.

\subsection{Methane}

Methane concentrations were highly variable, ranging between 25 and $505 \mathrm{nM}$, and always highly oversaturated (850$21700 \%$ ), in accordance with data from other temperate and tropical streams and rivers (e.g., Jones and Mulholland, 1998; Middelburg et al., 2002; Abril et al., 2005, 2007; Guérin et al., 2006 and references therein). $\mathrm{CH}_{4}$ concentrations in rivers result from the balance between inputs from groundwaters followed by transport with water masses, production in river sediments, and losses due to oxidation in waters and surface sediments and to the outgassing to the atmosphere. The relatively low (below $100 \mathrm{nM}$ ) $\mathrm{CH}_{4}$ concentrations in the low-order tributaries of the Tana River, at high and intermediate elevations, suggest that soil $\mathrm{CH}_{4}$ inputs were moderate in this area at that season. In some US temperate rivers, Jones and Mulholland (1998) have found a $\mathrm{CH}_{4}$ maximum in small headwater streams at highest elevation, but also at highest organic soil content, they attributed to large $\mathrm{CH}_{4}$ groundwater inputs from soils. This trend does not appear in the tributaries of the Tana River. Along the main course of the Tana River, $\mathrm{CH}_{4}$ concentrations were also relatively low (around or below $100 \mathrm{nM}$ ), with the exception of the vicinity of the Masinga reservoir and in the delta (Fig. 4b). Such generally low $\mathrm{CH}_{4}$ concentrations suggest moderate production in the river itself, in comparison with other rivers, where $\mathrm{CH}_{4}$ maxima where found during low discharge periods (De Angelis and Lilley, 1987; De Angelis and Scranton, 1993; Abril et al., 2007).

Hydroelectric reservoirs have been shown to be substantial sources of $\mathrm{CH}_{4}$ emission to the atmosphere (St. Louis et al., 2000). Our data from Masinga reservoir show relatively high $\mathrm{CH}_{4}$ concentrations in the inflowing Tana River $(505 \mathrm{nM})$ and in the outflow of the reservoir $(372 \mathrm{nM})$, but much lower concentrations in the upper water column $(51 \pm 7 \mathrm{nM})$. High concentration at the entrance of the reservoir is probably due to intense local sedimentation in this area where water current decreases. High sedimentation promotes methane production and diffusion in the water column, which is likely still well mixed in this area. High methane production probably occurs also in the deeper reservoir, but as the water column appears stratified, it affects only the deeper, anoxic waters. The lower concentrations in surface waters are most likely the result of high oxidation rates of methane diffusing from anoxic bottom waters into the oxic upper water layer, as reported in other tropical reservoirs (e.g., Guérin and Abril, 2007). The relatively high $\mathrm{CH}_{4}$ concentrations at the outflow of the reservoir is due to the deep location of the outlet where $\mathrm{CH}_{4}$-rich anoxic water are passing. Part of the $\mathrm{CH}_{4}$ escapes to the atmosphere immediately downstream of the dam due pressure change and high turbulence, while further degassing may occur downstream in the river (Guérin et al., 2006). $\mathrm{CH}_{4}$ concentrations further downstream are much lower (Fig. 4b), consistent with important further $\mathrm{CH}_{4}$ degassing and/or oxidation within the river. Towards the Tana Delta, however, an increase in $\mathrm{CH}_{4}$ concentrations is observed with highest concentrations in the most downstream site $(387 \mathrm{nM})$, which suggests increased lateral or sediment $\mathrm{CH}_{4}$ inputs in the delta wetlands.

\subsection{Importance of internal sediment storage and resus- pension}

The most striking pattern in the suspended matter data is the gradual but steep increase in TSM observed along the middle and lower course of the main Tana River, from low values of 15.2 and $12.2 \mathrm{mg} \mathrm{L}^{-1}$ before and after Masinga reservoir, respectively, to $483 \mathrm{mg} \mathrm{L}^{-1}$ in the most downstream sampling station (Fig. 6). As sampling was conducted during the dry season, no more tributary inputs reach the Tana River below the Nyambene Hills tributaries (Fig. 1), suggesting that the main part of this increase in TSM is caused by resuspension of internally stored sediment. In various other tropical river systems, sediment delivery is observed to be highly episodic or concentrated in short-term periods with highest precipitation (e.g., Townsend-Small et al., 2007, Hilton et al., 2008). According to Dunne (1979), 35-75\% of sediment delivery to Kenyan river systems is thought to occur during periods when water flow is in the highest $1 \%$ range of flow rates, depending on the dominant land use in the catchments (e.g., with a much higher fraction of sediment delivery during such events for grazing lands compared to forest-dominated catchments). With this in mind, substantial within-channel sediment storage appears highly likely. Kitheka et al. (2005) provide some data on the seasonality of discharge and TSM concentrations at Garsen (corresponding to our sampling station 24) and found that peak TSM concentrations typically preceded discharge peaks - suggesting the release of relatively mobile sediment during the first stages of river discharge increases. The latter is consistent with observations in other large river systems such as the Amazon, Mississippi and Orinoco where a seasonal cycle of sediment storage and resuspension has been observed (Meade et al., 1985; Meade, 1988; Mossa, 1996). Along a $900 \mathrm{~km}$ transect of the lower Mississippi, for example, Mossa (1996) observed both downstream increases and decreases of TSM levels depending on river discharge stage. The deposition/resuspension cycles in large river networks appear to be governed mainly by seasonal changes in river discharge and river slope (Meade, 1988), but the presence of floodplains allowing temporal deposition and retention also play a role. To our knowledge, the $\sim 30$-fold downstream increase in TSM concentrations 
observed along the Tana River during our sampling period is much more pronounced than that observed in the mainstem of any other river system so far. Seasonal altitudinal profiles of TSM concentrations during different stages of river discharge will be required to further document deposition and resuspension cycles in this river system, and its consequences for $\mathrm{C}$ and nutrient cycling.

An important implication of such pronounced resuspension events is that much of the suspended matter observed in the lower Tana River has likely experienced a much longer residence time within the river system compared to the (smaller) pool of TSM in the higher reaches of the Tana River, i.e. the gradient in TSM concentrations is expected to coincide with a gradient of lower to higher residence time within the system. The longer residence time creates opportunities for biogeochemical processing of the associated organic matter (Battin et al., 2008) which become evident when comparing the observed biogeochemical characteristics of particulate OC between the upper and lower Tana River (see below).

\subsection{Organic matter changes along the river continuum}

Riverine carbon is either produced within or delivered to the river. The contribution of phytoplankton production to stock of POC can be estimated from C/chl- $a$ ratios. The observed ratios in the river Tana and its tributaries are much higher than those typically found in phytoplankton ( $>500$; Fig. 11b, typical ratios for phytoplankton $\sim 50$ ), implying that more than $90 \%$ of the particulate organic carbon is detrital. Soil organic carbon content appeared to be an important factor influencing riverine \% $\mathrm{POC} / \mathrm{TSM}$ for the tributaries (data not shown), but the latter were consistently higher than soil \%OC (top $5 \mathrm{~cm}$ ), indicating that suspended particulate organic carbon was also derived from direct litter inputs and/or from topsoil layers, where \%OC is likely higher than in the top $5 \mathrm{~cm}$ profile which was sampled here. Similarly, $\delta^{13} \mathrm{C}_{\mathrm{POC}}$ signatures in the 11 tributary streams were significantly correlated to those in soil organic matter ( $p=0.02$, data not shown), but the $\delta^{13} \mathrm{C}$ range was much narrower in suspended matter $(-26.5$ to $-22.7 \%$ o $)$ than in soils $(-26.5$ to $-13.2 \%$ o). The latter pattern is not unexpected given that soil $\delta^{13} \mathrm{C}$ values in these subcatchments (which all appear to have mixed $\mathrm{C} 3$ and $\mathrm{C} 4$ vegetation) are heterogeneous and vary spatially depending on the dominant vegetation, resulting in an 'averaged' mixed $\delta^{13} \mathrm{C}$ signature in riverine suspended matter.

The strong downstream increase in TSM concentrations along the main Tana River (Fig. 6a) coincides with a strong increase in POC (Fig. 6b), but the latter is less pronounced, as a result, \%POC/TSM decreased from $4.6 \%$ below Masinga reservoir to $\sim 1.1 \%$ in the most downstream sampling stations (Fig. 7). Given that the increase in TSM concentrations can be linked to resuspension of internally stored sediment (see above), this significant decrease in \%POC/TSM can be interpreted as an important loss of mineral-associated organic carbon during particle residence within the river system. If we assume that the original \%POC/TSM during the time of sediment delivery to the river system is similar to that observed in TSM in the upper Tana River, we estimate that $\sim 75 \%$ of particle-associated organic carbon was remineralized during its riverine transit. This estimate should be considered as very preliminary, since future seasonal data are are required to confirm our assumption that \%POC/TSM of sediment inputs during high sediment influx events are similar to those observed upstream here during the dry season.

The specific surface areas measured on five of the Tana River TSM samples from the lower river are very high $\left(63.6-82.2 \mathrm{~m}^{2} \mathrm{~g}^{-1}\right)$ compared to values reported for coastal sediments, estuaries and rivers (typically $<50 \mathrm{~m}^{2} \mathrm{~g}^{-1}$ ), and OC:SA ratios found here $\left(0.16-0.22 \mathrm{mg} \mathrm{C} \mathrm{m}^{-2}\right)$ are consequently in the lower range of those reported in the literature (e.g., Keil et al., 1997; Aufdenkampe et al., 2007). The SA values in TSM are also consistently higher than those observed in surface soils ( $<63 \mu \mathrm{m}$ fraction) which ranged between 11.8 and $67.7 \mathrm{~m}^{2} \mathrm{~g}^{-1}$ (data not shown). Soil OC:SA ratios $\left(0.12\right.$ to $3.76 \mathrm{mg} \mathrm{C} \mathrm{m}^{-2}$, one exceptionally high value of $13.6 \mathrm{mg} \mathrm{C} \mathrm{m}^{-2}$ ) were highly variable and generally higher those of riverine particles $\left(0.220\right.$ to $\left.0.143 \mathrm{mg} \mathrm{C} \mathrm{m}^{-2}\right)$, indicating that riverine particles have been subjected to extensive degradation losses. Moreover, the downstream decrease in \%POC/TSM observed in the main Tana River appears, based on the few SA measurements made on these TSM samples, to match also with a decreased surface loading of organic carbon on these particles (OC:SA from 0.220 to $0.143 \mathrm{mg} \mathrm{C} \mathrm{m}^{-2}$ between station 20 and 24).

$\delta^{13} \mathrm{C}_{\mathrm{POC}}$ signatures below Masinga reservoir are ${ }^{13} \mathrm{C}$ depleted $(-25.2 \%)$ relative to those observed upstream of the reservoir $(-22.8 \%$, Fig. 9). In combination with the low $\delta^{13} \mathrm{C}$ signatures in Masinga reservoir surface waters $(-29.0 \pm 0.3 \%$ o), which appear to are dominated by phytoplankton biomass (based on the low POC:chl- $a$ ratios, Fig. 11b), suggest that part of the POC export from Masinga reservoir is derived from phytoplankton production in the reservoir. The subsequent downstream sampling site on the Tana River, however, shows a distinctly higher $\delta^{13} \mathrm{C}_{\mathrm{POC}}$ $(-21.5 \%$, i.e., a shift of $3.7 \%$ ) and a large concurrent decrease in \%POC/TSM (from 4.6 to $2.0 \%$ ). The combination of these data allow us to estimate the expected $\delta^{13} \mathrm{C}$ signature of the POC lost in this section of the river at $\sim-28.0 \%$. This signature suggests that the ${ }^{13} \mathrm{C}$-depleted fraction (which likely consists of phytoplankton biomass from the reservoir) was rapidly and preferentially degraded, consistent with earlier observations in other tropical reservoirs (De Junet et al., 2009). Further downstream, $\delta^{13} \mathrm{C}_{\mathrm{POC}}$ shows relatively minor variations $(-22.9$ to $-22.2 \%$ ) until the most downstream station in the Tana delta where $\delta^{13} \mathrm{C}_{\text {POC }}$ increases $(-21.2 \%$ ). Since marine inputs can be excluded in the freswhater part of the delta, the latter trend could suggest an increased contribution of local $\mathrm{C} 4$ material (which would be consistent also with the slight increase in \% POC/TSM). In contrast to the 
marked changes in the composition of POC before and after Masinga reservoir, DOC concentrations and $\delta^{13} \mathrm{C}$ signatures are markedly uniform between the Tana River before and after the reservoir, and in surface waters of Masinga reservoir. None of the $\delta^{13} \mathrm{C}_{\mathrm{POC}}$ variations along the Tana River between Meru and Garsen (Fig. 1) are correlated with changes in \%POC/TSM; interpreted in the context of progressive degradation of $\mathrm{POC}$, this suggest that little selectivity in remineralization of $\mathrm{C} 3$ and $\mathrm{C} 4$-derived carbon occurs.

Radiocarbon data on POC $\left(\Delta^{14} \mathrm{C}_{\mathrm{POC}}\right)$, available for limited number of sites along the Tana River, ranged between -116 and $-35 \%$ o (i.e., ${ }^{14} \mathrm{C}$ age of $\sim 935$ to $\sim 230 \mathrm{yr}$ ). Raymond and Bauer (2001) were among the first to demonstrate that rivers may deliver relativey old, ${ }^{14} \mathrm{C}$-depleted $\mathrm{POC}$ to the coastal zone, while DOC is often younger in age. Both experimental work (e.g., Raymond and Bauer, 2001) and field data (e.g., McCallister et al., 2004; Mayorga et al., 2005) have suggested that intensive bacterial remineralization can occur selectively, and hence substantially alter the age and composition of organic ultimately exported. In our dataset, there is a general decrease in $\Delta^{14} \mathrm{C}_{\mathrm{POC}}$ along the lower Tana River, which coincides with the overall decrease in \%POC/TSM (Fig. 10). Interpreting the gradual decrease in \%POC/TSM in terms of remineralization of POC during the residence period of particles within the river system, this decrease in ${ }^{14} \mathrm{C}$ age of associated $\mathrm{POC}$ indicates selective remineralization of a modern POC fraction (estimated $\Delta{ }^{14} \mathrm{C}$ of +56 to $+140 \%$, depending on whether or not the data from station 11 are included in the regression used), imprinting the residual carbon delivered to the estuary and delta with an old, ${ }^{14} \mathrm{C}$-depleted signature. Alternatively, within river primary production would add ${ }^{14} \mathrm{C}$-old organic carbon because of the very low $\Delta^{14} \mathrm{C}_{\text {DIC }}$ numbers (Table 2 ), but this freshly produced material is likely readily remineralised and will thus not contribute to POC pools.

DOC concentrations ranged between 0.3 and $2.5 \mathrm{mg} \mathrm{L}^{-1}$, with the majority of data in a fairly narrow range between 0.6 and $1.2 \mathrm{mg} \mathrm{L}^{-1}$ (Fig. 8a). DOC was the largest organic carbon pool in high altitude tributaries (DOC/POC ratios of $1.9 \pm 0.2$, Fig. $8 b$ ) while POC dominated in tributaries draining Mt. Kenya and Nyambene Hills (DOC/POC ratios of $0.8 \pm 0.3$ ). Along the main Tana River, DOC concentrations varied within a very narrow range $\left(0.98 \pm 0.14 \mathrm{mg} \mathrm{L}^{-1}\right.$, Fig. 8a), contrasting sharply with the steep downstream increase in POC concentrations (Fig. 6b). DOC concentrations in the lower Tana River are markedly lower than those observed in other large African rivers such as the Congo, Nile, Gambia and Niger (Martins and Probst, 1991), but consistent with average values for semi-arid climates presented in Spitzy and Leenheer (1991). As a result of the contrast in DOC and POC concentration profiles, DOC/POC ratios declined from $\sim 1.6$ in the vicinity of Masinga reservoir to 0.2 along the lower Tana River (Fig. 8b), and were inversely related to logarithm of TSM concentrations (Fig. 8c). An inverse relationship between $\log (\mathrm{TSM})$ and DOC/POC ratios has been observed in a wide range of river systems and estuaries (e.g., Ittekkot and Laane, 1991; Abril et al., 2002; Middelburg and Herman, 2008; Ralison et al., 2008). When comparing our data from headwater streams, the main Tana River, and data from the freshwater part of the Tana estuary (Bouillon et al., 2007, Fig. 8c), however, different patterns in the DOC/POC versus $\log$ (TSM) relationship can be discerned. While the slope of the relationships appear fairly similar, DOC/POC ratios are lower in the headwater streams compared to the main river for similar TSM values, and DOC/POC ratios from the freshwater estuary are higher than those found here on the main Tana River (Fig. 8c).

The DOC/POC ratios in the most downstream stations are markedly lower than those observed in the freshwater and oligohaline part of the estuary (1.4 \pm 1.3 , Bouillon et al., 2007), suggesting either pronounced seasonal variations or substantial additional lateral DOC inputs in the upper tidal range of the river. $\delta^{13} \mathrm{C}_{\mathrm{DOC}}$ along the Tana River varied little (overall range between -24.0 and $-22.7 \%$ ), and in contrast to POC, did not show a marked depletion in ${ }^{13} \mathrm{C}$ either in surface waters of Masinga reservoir $(-23.9 \pm 0.3 \%$ o or at the outflow of the reservoir $(-23.9 \%$ ). Thus, in contrast to POC, phytoplankton production in Masinga reservoir surface waters appeared to have little impact on surface water $\delta^{13} C_{\text {DOC }}$. This suggests that either little excretion of DOC occurs during primary production in this system, or that labile algae-derived DOC is rapidly remineralized or photooxidized in the reservoirs surface waters, with little net effect on overall DOC concentrations and $\delta^{13} \mathrm{C}$ signatures. Overall, $\delta^{13} \mathrm{C}_{\mathrm{DOC}}$ and $\delta^{13} \mathrm{C}_{\mathrm{POC}}$ were clearly uncoupled and showed a relatively weak relationship (Fig. 9c), suggesting that despite clear evidence for partitioning of OC between POC and DOC (i.e., the relationships between DOC/POC and TSM described above), a large fraction of the POC pool does not readily or dynamically exchange with dissolved $\mathrm{C}$ pools.

Acknowledgements. We thank Pieter van Rijswijk, Peter van Breugel, and Marco Houtekamer (NIOO-CEME), Jacques Navez (KMMA, Tervuren), Mathieu Boudin (KIK, Brussels), Dominique Poirier (EPOC, Bordeaux), and Xiaomei Xu (UC Irvine) for analytical assistance. Stéphanie Duvail and Olivier Hamerlynck provided stimulating discussions, Gabriel Kung`u provided excellent company and assistance in the field, and David P. Gillikin provided useful comments on a draft version of this ms. Two anonymous referees provided excellent and constructive comments on the original version of this manuscript. This research was supported by the FWO-Vlaanderen (contracts G.0632.06, G.0395.07, and travel grant to S.B.), and by the Netherlands Organisation for Scientific Research (PIONIER). This is publication 4646 of the Netherlands Institute of Ecology (NIOO-KNAW).

Edited by: T. J. Battin 


\section{References}

Abril, G., Nogueira, M., Etcheber, H., Cabaçadas, G., Lemaire, E., and Brogueira, M. J.: Behaviour of organic carbon in nine contrasting european estuaries, Estuar. Coast. Shelf S., 54, 241-262, 2002.

Abril, G. and Iversen, N.: Methane dynamics in a shallow, nontidal, estuary (Randers Fjord, Denmark), Mar. Ecol.-Prog. Ser., 230, 171-181, 2002.

Abril, G., Guérin, F., Richard, S., Delmas, R., Galy-Lacaux, C., Gosse, P., Tremblay, A., Varfalvy, L., Dos Santos, M. A., and Matvienko, B.: Carbon dioxide and methane emissions and the carbon budget of a 10-year old tropical reservoir (PetitSaut, French Guiana), Global Biogeochem. Cy., 19, GB4007, doi:10.1029/2005GB002457, 2005.

Abril, G., Commarieu, M. V., and Guérin, F: Enhanced methane oxidation in an estuarine turbidity maximum, Limnol. Oceanogr., 52, 470-475, 2007.

Alin, S. R., Aalto, R., Goñi, M. A., Richey, J. E., and Dietrich, W. E.: Biogeochemical characterization of carbon sources in the Strickland and Fly rivers, Papua New Guinea, J. Geophys. Res., 113, F01S05, doi:10.1029/2006JF000625, 2008.

Aucour, A. M., Sheppard, S. M. F., Guyomar, O., and Wattelet, J.: Use of ${ }^{13} \mathrm{C}$ to trace origin and cycling of inorganic carbon in the Rhône river system, Chem. Geol., 159, 87-105, 1999.

Aucour, A. M., France-Lanord, C., Pedoja, K., Pierson-Wickman, A. C., and Sheppard, S. M. F.: Fluxes and sources of particulate organic carbon in the Ganga-Brahmaputra river system, Global Biogeochem. Cy., 20, GB1006, doi:10.1029/2004GB002324, 2006.

Aufdenkampe, A. K., Mayorga, E., Hedges, J. I., Llerena, C., Quay, P. D., Gudeman, J., Krusche, A. V., and Richey, J. E.: Organic matter in the Peruvian headwaters of the Amazon: compositional evolution from the Andes to the lowland Amazon mainstem, Org. Geochem., 38, 337-364, 2007.

Battin, T. J., Kaplan, L. A., Findlay, S., Hopkinson, C. S., Marti, E., Packman, A. I., Newbold, J. D., and Sabater, F.: Biophysical controls on organic carbon fluxes in fluvial networks, Nat. Geosci., 1, 95-100, 2008.

Bernardes, M. C., Martinelli, L. A., Krusche, A. V., Gudeman, J., Moreira, M., Victoria, R. L., Ometto, J. P. H. B., Ballester, M. V. R., Aufdenkampe, A. K., Richey, J. E., and Hedges, J. I.: Riverine organic matter composition as a function of land use changes, southwest Amazon, Ecol. Appl., 14, S263-S279, 2004.

Bird, M. I., Giresse, P., and Chivas, A. R.: Effect of forest and savanna vegetation on the carbon isotope composition of sediments from the Sanaga River, Cameroon, Limnol. Oceanogr., 39, 18451854, 1994.

Borges, A. V.: Do we have enough pieces of the jigsaw to integrate $\mathrm{CO}_{2}$ fluxes in the Coastal Ocean?, Estuaries, 28, 3-27, 2005

Bouillon, S. and Boschker, H. T. S.: Bacterial carbon sources in coastal sediments: a cross-system analysis based on stable isotope data of biomarkers, Biogeosciences, 3, 175-185, 2006, http://www.biogeosciences.net/3/175/2006/.

Bouillon, S., Dehairs, F., Schiettecatte, L. S., and Borges, A.V.: Biogeochemistry of the Tana estuary and delta (northern Kenya), Limnol. Oceanogr., 52, 46-59, 2007.

Brandes, J. A. and Devol, A. H.: Isotopic fractionation of oxygen and nitrogen in coastal marine sediments, Geochim. Cosmochim. Ac., 61, 1793-1801, 1997.
Brunet, F., Gaiero, D., Probst, J. L., Depetris, P. J., Lafaye, F. G., and Stille, P.: $\delta^{13} \mathrm{C}$ tracing of dissolved inorganic carbon sources in Patagonian rivers (Argentina), Hydrol. Process., 19, 33213341, 2005.

Cole, J. J. and Caraco, N. F.: Carbon in catchments: connecting terrestrial carbon losses with aquatic metabolism, Mar. Freshwater Res., 52, 101-110, 2001.

Cole, J. J., Caraco, N. F., Kling, G. W., and Kratz, T. K.: Carbon dioxide supersaturation in the surface waters of lakes, Science, 265, 1568-1570, 1994.

Cole, J. J., Prairie, Y. T., Caraco, N. F., McDowell, W. H., Tranvik, L. J., Striegl, R. G., Duarte, C. M., Kortelainen, P., Downing, J. A., Middelburg, J. J., and Melack, J.: Plumbing the global carbon cycle: integrating inland waters into the terrestrial carbon budget, Ecosystems, 10, 171-184, 2007.

Coynel, A., Seyler, P., Etcheber, H., Meybeck, M., and Orange, D.: Spatial and seasonal dynamics of total suspended sediment and organic carbon species in the Congo River, Global Biogeochem. Cy., 19, GB4019, doi:10.1029/2004GB002335, 2005.

De Angelis, M. A. and Lilley, M. D.: Methane in surface waters of Oregon estuaries and rivers, Limnol. Oceanogr., 32, 716-722, 1987.

De Angelis, M. A. and Scranton, M. I.: Fate of methane in the Hudson river and estuary, Global Biogeochem. Cy., 7, 509-523, 2003.

Deborde, J., Anschutz, P., Chaillou, G., Etcheber, H., Commarieu, M. V., Lecroart, P., and Abril, G.: The dynamics of phosphorus in turbid estuarine systems: example of the Gironde estuary (France), Limnol. Oceanogr., 52, 862-872, 2008.

De Junet, A., Abril, G., Guérin, F., Billy, I., and De Wit, R.: A multi-tracers analysis of sources and transfers of particulate organic matter in a tropical reservoir (Petit Saut, French Guiana), River. Res. Appl., 25, 253-271, 2009.

del Giorgio, P. A. and Pace, M. L.: Relative independence of dissolved organic carbon transport and processing in a large temperate river: the Hudson River as both pipe and reactor, Limnol. Oceanogr., 53, 185-197, 2008.

Doctor, D. H., Kendall, C., Sebestyen, S. D., Shanley, J. B., Ohte, N., and Boyer, E.W.: Carbon isotope fractionation of dissolved inorganic carbon (DIC) due to outgassing of carbon dioxide from a headwater stream, Hydrol. Process., 22, 2410-2423, 2008.

Drenzek, N. J., Hughen, K. A., Montluçon, D. B., Southon, J. R., dos Santos, G. M., Druffel, E. R. M., Giosan, L., and Eglinton, T. I.: A new look at old carbon in active margin sediments, Geology, 37, 239-242, 2009.

Duarte, C. M. and Prairie, Y. T.: Prevalence of heterotrophy and atmospheric $\mathrm{CO} 2$ emissions from aquatic ecosystems, Ecosystems, 8, 862-870, 2005.

Dunne, T. and Ongweny, G. S. O.: A new estimate of sedimentation rates on the upper Tana River, The Kenyan Geographer, 2, 109$126,1976$.

Dunne, T.: Sediment yield and land use in tropical catchments, J. Hydrol., 42, 281-300, 1979.

Dunne, T.: Evaluation of erosion conditions and trends. In: Guidelines for Watershed Management, FAO Conservation guide $\mathrm{n}^{o} 1$, 1977.

Evans, D. J., Johnes, P. J., and Lawrence, D. S.: Physico-chemical controls on phosphorus cycling in two lowland streams. Part 2 the sediment phase, Sci. Total Environ., 329, 165-182, 2004. 
Evans, M. J., Derry, L. A., and France-Lanord, C.: Degassing of metamorphic carbon dioxide from the Nepal Himalaya, Geochem. Geophy. Geosy., 9, Q04021, doi:10.1029/2007GC001796, 2008.

Fox, L. E.: A model for inorganic control of phosphate concentrations in river waters, Geochim. Cosmochim. Ac., 53, 417-428, 1989.

Fox, L. E., Sager, S. L., and Wofsy, S. C.: The chemical control of soluble phosphorus in the Amazon estuary, Geochim. Cosmochim. Ac., 50, 783-794, 1986.

Frankignoulle, M. and Borges, A. V.: Direct and indirect $p \mathrm{CO}_{2}$ measurements in a wide range of $p \mathrm{CO}_{2}$ and salinity values (the Scheldt estuary), Aquat. Geochem., 7, 267-273, 2001.

Gaillardet, J. and Galy, A.: Himalaya - carbon sink or source?, Science, 320, 1727-1728, 2008.

Galy, V., France-Lanord, C., and Lartiges, B.: Loading and fate of particulate organic carbon from the Himalaya to the GangaBrahmaputra delta, Geochim. Cosmochim. Ac., 72, 1767-1787, 2008.

Gillikin, D. P. and Bouillon, S.: Determination of $\delta^{18} \mathrm{O}$ of water and $\delta^{13} \mathrm{C}$ of dissolved inorganic carbon using a simple modification of an elemental analyzer - isotope ratio mass spectrometer (EA-IRMS): an evaluation, Rapid Commun. Mass Sp., 21, 14751478, 2007.

Gillson, L., Waldron, S., and Willis, K. J.: Interpretation of soil $\delta^{13} \mathrm{C}$ as an indicator of vegetation change in African savannas, $\mathrm{J}$. Veg. Sci., 15, 339-350, 2004.

Guérin, F. and Abril, G.: Significance of pelagic aerobic methane oxidation in the methane and carbon budget of a tropical reservoir, J. Geophys. Res., 112, G03006, doi:10.1029/2006JG000393, 2007.

Guérin, F., Abril, G., Richard, S., Burban, B., Reynouard, C., Seyler, P., and Delmas, R.: Methane and carbon dioxide emissions from tropical reservoirs: significance of downstream rivers, Geophys. Res. Lett., 33, L21407, doi:10.1029/2006GL027929, 2006.

Guy, R. D., Fogel, M. L., and Berry, J. A.: Photosynthetic fractionation of the stable isotopes of oxygen and carbon, Plant Physiol., 101, 37-47, 1993.

Harrison, J. A., Maranger, R. J., Alexander, R. B., Giblin, A. E., Jacinthe, P. A., Mayorga, E., Seitzinger, S. P., Sobota, D. J., and Wollheim, W. M.: The regional and global significance of nitrogen removal in lakes and reservoirs, Biogeochemistry, 93, 143157, 2009.

Hedges, J. I., Cowie, G. L., Richey, J. E., Quay, P. D., Benner, R., Strom, M., and Forsberg, B. R.: Origins and processing of organic matter in the Amazon River as indicated by carbohydrates and amino acids, Limnol. Oceanogr., 39, 743-761, 1994.

Heimsath, A. M., Dietrich, W. E., Nishiizumi, K., and Finkel, R. C.: The soil production function and landscape equilibrium, Nature, 388, 358-361, 1997.

Hilton, R. G., Galy, A., Hovius, N., Chen, M. C., Horng, M. J., and Chen, H.: Tropical-cyclone-driven erosion of the terrestrial biosphere from mountains, Nature Geoscience, 1, 759-762, 2008.

Holmes, R. M., McClelland, J. W., Raymond, P. A., Frazer, B. B., Peterson, B. J., and Stieglitz, M.: Lability of DOC transported by Alaskan rivers to the arctic ocean, Geophys. Res. Lett., 35, L03402, doi:10.1029/2007GL032837, 2008.

Ittekkot, V., Humborg, C., and Schäfer, P.: Hydrological alterations and marine biogeochemistry: a silicate issue?, Bioscience, 50, 776-782, 2000.

Ittekkot, V. and Laane, R. W. P. M.: Fate of riverine particulate organic matter, in: Biogeochemistry of major world rivers, edited by: Degens, E. T., Kempe, S., and Richey, J. E., Wiley, 233-243, 2001.

Johnson, M. S., Lehmann, J., Riha, S. J., Krusche, A. V., Richey, J. E., Ometto, J. P. H. B., and Couto, E. G.: $\mathrm{CO}_{2}$ efflux from Amazonian headwater streams represents a significant fate for deep soil respiration, Geophys. Res. Lett., 35, L17401, doi:10.1029/2008GL034619, 2008.

Jones, J. B. and Mulholland, P. J.: Influence of drainage basin topography and elevation on carbon dioxide and methane supersaturation of stream water, Biogeochemistry, 40, 57-72, 1998.

Keil, R. G., Mayer, L. M., Quay, P. D., Richey, J. E., and Hedges, J. I.: Loss of organic matter from riverine particles in deltas, Geochim. Cosmochim. Ac., 61, 1507-1511, 1997.

King, B. C. and Chapman, G. R.: Volcanism of the Kenyan rift valley, Philos. T. R. Soc. S.-A., 171, 185-208, 1972.

Kitheka, J. U., Obiero, M., and Nthenge, P.: River discharge, sediment transport and exchange in the Tana estuary, Kenya, Estuar. Coast. Shelf S., 63, 455-468, 2005.

Ludwig, W., Amiotte-Suchet, P., and Probst, J. L.: River discharges of carbon to the world's oceans: determining local inputs of alkalinity and of dissolved and particulate organic carbon, C.R. Acad. Sci. II, 323, 1007-1014, 1996.

Maingi, J. K. and Marsh, S. E.: Quantifying hydrologic impacts following dam construction along the Tana River, Kenya, J. Arid Environ., 50, 53-79, 2002.

Martinelli, L. A., Ballester, M. V., Krusche, A. V., Victoria, R. L., de Camargo, P. B., Bernardes, M., and Ometto, J. P. H. B.: Landcover changes and $\delta^{13} \mathrm{C}$ composition of riverine particulate organic matter in the Piracicaba river basin (southeast region of Brazil), Limnol. Oceanogr., 44, 1826-1833, 1999.

Masiello, C. A.: Quick burial at sea, Nature, 450, 360-361, 2007.

Mayer, L. M.: Surface area control of organic carbon accumulation in continental shelf sediments, Geochim. Cosmochim. Ac., 58, 1271-1284, 1994.

Mayorga, E., Aufdenkampe, A. K., Masiello, C. A., Krusche, A. V., Hedges, J. I., Quay, P. D., Richey, J. E., and Brown, T. A.: Young organic matter as a source of carbon dioxide outgassing from Amazonian rivers, Nature, 436, 538-541, 2005.

McCallister, S. L., Bauer, J. E., Cherrier, J. E., and Ducklow, H. W.: Assessing sources and ages of organic matter supporting river and estuarine bacterial production: A multiple-isotope $\left(\Delta^{14} \mathrm{C}\right.$, $\delta^{13} \mathrm{C}$, and $\left.\delta^{15} \mathrm{~N}\right)$ approach, Limnol. Oceanogr., 49, 1687-1702, 2004.

McClain, M. E., Boyer, E. W., Dent, L., Gergel, S. E., Grimm, N. B., Groffman, P. M., Hart, S. C., Harvey, J. W., Johnston, C. A., Mayorga, E., McDowell, W. H., and Pinay, G.: Biogeochemical hot spots and hot moments at the interface of terrestrial and aquatic ecosystems, Ecosystems, 6, 301-312, 2003.

McClain, M. E. and Naiman, R. J.: Andean influence on the biogeochemistry and ecology of the Amazon River, Bioscience, 58, 325-338, 2008.

Meade, R. H.: Movement and storage of sediment in river systems, in: Physical and chemical weathering in geochemical cycles, edited by: Lerman, A. and Meybeck, M., Kluwer, 165-179, 1988. 
Meade, R. H., Dunne, T., Richey, J. E., Santos, U. M., and Salati, E.: Storage and remobilization of suspended sediment in the lower Amazon River of Brazil, Science, 228, 488-490, 1985.

Meybeck, M. and Vörösmarty, C.: Fluvial filtering of land-to-ocean fluxes: from natural Holocene variations to Anthropocene, C.R. Geosci., 337, 107-123, 2005.

Middelburg, J. J., Nieuwenhuize, J., Iversen, N., Høgh, N., De Wilde, H., Helder, W., Seifert, R., and Christof, O.: Methane distribution in European tidal estuaries, Biogeochemistry, 59, 95119, 2002.

Middelburg, J. J. and Herman, P. M. J.: Organic matter processing in tidal estuaries, Mar. Chem., 106, 127-147, 2007.

Mossa, J.: Sediment dynamics in the lowermost Mississippi River, Eng. Geol., 45, 457-479, 1996.

Mutua, B. M., Klik, A., and Loiskand, L.: Predicting sediment loading into Masinga Reservoir and its storage capacity reduction, Int. Symp. Water Manage. Hydraul. Engineer., Austria, 2005.

Osburn, C. L. and St-Jean, G.: The use of wet chemical oxidation with high-amplification isotope ratio mass spectrometry (WCOIRMS) to measure stable isotope values of dissolved organic carbon in seawater, Limnol. Oceanogr.-Meth., 5, 296-308, 2007.

Piésold, D. D., Tattersfield, J., and Hodgson, C. W.: Masinga Dam in Kenya, Proc. Instn. Civ. Engrs., Part 1, 76, 999-1025, 1985.

Quay, P. D., Wilbur, D. O., Richey, J. E., Devol, A. H., Benner, R., and Forsberg, B. R.: The ${ }^{18} \mathrm{O}:{ }^{16} \mathrm{O}$ of dissolved oxygen in rivers and lakes in the Amazon Basin: determining the ratio of respiration to photosynthesis in freshwaters, Limnol. Oceanogr., 40, 718-729, 1995.

Ralison, O., Dehairs, F., Middelburg, J. J., Borges, A. V., and Bouillon, S.: Carbon biogeochemistry in the Betsiboka estuary (northwestern Madagascar), Org. Geochem., 39, 1649-1658, 2008.

Raymond, P. A. and Bauer, J. E.: Use of ${ }^{14} \mathrm{C}$ and ${ }^{13} \mathrm{C}$ natural abundances for evaluating riverine, estuarine, and coastal DOC and POC sources and cycling: a review and synthesis, Org. Geochem., 32, 469-485, 2001.

Raymond, P.A., Oh, N.H., Turner, R.E., and Broussard, W.: Anthropogenically enhanced fluxes of water and carbon from the Mississippi River, Nature, 451, 449-52, 2008.

Richey, J. E., Melack, J. M., Aufdenkampe, A. K., Ballester, M. V., and Hess, L. L.: Outgassing from Amazonian rivers and wetlands as a large tropical source of atmospheric $\mathrm{CO}_{2}$, Nature, 416, 617620, 2002.

Saenyi, W. W.: Temporal and spatial sediment modelling in Masinga Reservoir, Kenya, Bodenkultur, 54, 207-213, 2003.

Schneider, H. M.: Sediment sources to Masinga Dam, in: Land and Water Management in Kenya, edited by: Gichuki, F. N., Mungai, D. N., Gachene, C. K., and Thomas, D. B., published by Soil and Water Conservation Branch, Ministry of Agriculture and Rural development, Nairobi, Kenya, 2000.

Snoussi, M., Kitheka, J., Shaghude, Y., Kane, A., Arthurson, R., Le Tissier, M., and Virji, H.: Downstream and coastal impacts of damming and water abstraction in Africa, Environ. Manage., 39, 587-600, 2007.
Sobek, S., Tranvik, L. J., and Cole, J. J.: Temperature independence of carbon dioxide supersaturation in global lakes, Global Biogeochem. Cy., 19, GB2003, doi:10.1029/2004GB002264, 2005.

Stuiver, M. and Polach, H. A.: Reporting of C-14 data - discussion, Radiocarbon, 19, 355-363, 1977.

St-Jean, G.: Automated quantitative and isotopic $\left({ }^{13} \mathrm{C}\right)$ analysis of dissolved inorganic carbon and dissolved organic carbon in continuous-flow using a total organic carbon analyser, Rapid Commun. Mass Sp., 17, 419-428, 2003.

St. Louis, V., Kelly, C., Duchemin, E., Rudd, J. W. M., and Rosenberg, D. M.: Reservoir surface as sources of greenhouse gases to the atmosphere: a global estimate, Bioscience, 20, 766- 775, 2000.

Syvitski, J. P. M., Vörösmarty, C. J., Kettner, A. J., and Green, P.: Impact of humans on the flux of terrestrial sediment to the global coastal ocean, Science, 308, 376-380, 2005.

Tobias, C. R., Böhlke, J. K., and Harvey, J. W.: The oxygen-18 approach for measuring aquatic metabolism in high-productivity waters, Limnol. Oceanogr., 52, 1439-1453, 2007.

Townsend-Small, A., McClain, M. E., and Brandes, J. A.: Contributions of carbon and nitrogen from the Andes Mountains to the Amazon River: evidence from an elevational gradient of soils, plants, and river material, Limnol. Oceanogr., 50, 672-685, 2005.

Townsend-Small, A., McClain, M. E., Hall, B., Noguera, J. L., Llerana, C. A., and Brandes, J. A.: Suspended sediments and organic matter in mountain headwaters of the Amazon River: results from a 1-year time series study in the central Peruvian Andes, Geochim. Cosmochim. Ac., 72, 732-740, 2008.

Uku, J. N. and Mavuti, K. M.: Comparative limnology, species diversity and biomass relationships of zooplankton and phytoplankton in five freshwater lakes in Kenya, Hydrobiologia, 272, 251-258, 1994.

Vörösmarty, C. J., Meybeck, M., Fekete, B., Sharma, K., Green, P., and Syvitski, J. P. M.: Anthropogenic sediment retention: major global impact from registered river impoundments, Global Planet. Change, 39, 169-190, 2003.

Walling, D. E.: The sediment yields of African rivers. Challenges in African hydrology and water resources, Proceedings of the Harare Symposium, July 1984, 265-283, 1984.

Williams, C. A., Hanan, N. P., Neff, J. C., Scholes, R. J., Berry , J. A., Denning, A. S., and Baker, D. F.: Africa and the global carbon cycle, Carbon Balance and Management, 2, 3, 2007.

Wollheim, W. M., Vörösmarty, C. J., Peterson, B. J., Seitzinger, S. P., and Hopkinson, C. S.: Relationship between river size and nutrient removal, Geophys. Res. Lett., 33, L06410, doi:10.1029/2006GL025845, 2006. 